\title{
Salt Tolerance Improvement in Rice through Efficient SNP Marker-Assisted Selection Coupled with Speed-Breeding
}

\author{
Md Masud Rana ${ }^{1,2}$, Takeshi Takamatsu ${ }^{1,3}$, Marouane Baslam $\left.{ }^{3}{ }^{(}\right)$, Kentaro Kaneko ${ }^{1}$, \\ Kimiko Itoh ${ }^{1,3}\left(\mathbb{D}\right.$, Naoki Harada ${ }^{1,3}(\mathbb{D})$, Toshie Sugiyama ${ }^{1,3}$, Takayuki Ohnishi ${ }^{4}$, \\ Tetsu Kinoshita ${ }^{5}$, Hiroki Takagi ${ }^{6}$ and Toshiaki Mitsui ${ }^{1,3, *(D)}$ \\ 1 Department of Life and Food Sciences, Graduate School of Science and Technology, Niigata University, \\ Niigata 950-2181, Japan; f16m502g@mail.cc.niigata-u.ac.jp (M.M.R.); takamatsutakeshi@yahoo.co.jp (T.T.); \\ k-neko@gs.niigata-u.ac.jp (K.K.); kimi@agr.niigata-u.ac.jp (K.I.); naharada@agr.niigata-u.ac.jp (N.H.); \\ sugiyama@agr.niigata-u.ac.jp (T.S.) \\ 5 Kihara Institute for Biological Research, Yokohama City University, Yokohama 244-0813, Japan; \\ tkinoshi@yokohama-cu.ac.jp \\ 6 Faculty of Bioresources and Environmental Sciences, Ishikawa Prefectural University, \\ Ishikawa 921-8836, Japan; h-takagi@ishikawa-pu.ac.jp \\ * Correspondence: t.mitsui@agr.niigata-u.ac.jp; Tel.: +81-25-262-6641
}

Received: 19 April 2019; Accepted: 22 May 2019; Published: 26 May 2019

\begin{abstract}
Salinity critically limits rice metabolism, growth, and productivity worldwide. Improvement of the salt resistance of locally grown high-yielding cultivars is a slow process. The objective of this study was to develop a new salt-tolerant rice germplasm using speed-breeding. Here, we precisely introgressed the $h s t 1$ gene, transferring salinity tolerance from "Kaijin" into high-yielding "Yukinko-mai" (WT) rice through single nucleotide polymorphism (SNP) marker-assisted selection. Using a biotron speed-breeding technique, we developed a $\mathrm{BC}_{3} \mathrm{~F}_{3}$ population, named "YNU31-2-4", in six generations and 17 months. High-resolution genotyping by whole-genome sequencing revealed that the $\mathrm{BC}_{3} \mathrm{~F}_{2}$ genome had $93.5 \%$ similarity to the WT and fixed only $2.7 \%$ of donor parent alleles. Functional annotation of $\mathrm{BC}_{3} \mathrm{~F}_{2}$ variants along with field assessment data indicated that "YNU31-2-4" plants carrying the $h s t 1$ gene had similar agronomic traits to the WT under normal growth condition. "YNU31-2-4" seedlings subjected to salt stress $(125 \mathrm{mM} \mathrm{NaCl})$ had a significantly higher survival rate and increased shoot and root biomasses than the WT. At the tissue level, quantitative and electron probe microanalyzer studies indicated that "YNU31-2-4" seedlings avoided $\mathrm{Na}^{+}$accumulation in shoots under salt stress. The "YNU31-2-4" plants showed an improved phenotype with significantly higher net $\mathrm{CO}_{2}$ assimilation and lower yield decline than WT under salt stress at the reproductive stage. "YNU31-2-4" is a potential candidate for a new rice cultivar that is highly tolerant to salt stress at the seedling and reproductive stages, and which might maintain yields under a changing global climate.
\end{abstract}

Keywords: $h s t 1 ; \mathrm{Na}^{+}$accumulation; SNP; rapid generation advance; salt tolerant; variant annotation; whole-genome sequencing 


\section{Introduction}

Projected climate change will aggravate a variety of abiotic stresses of rice plants, including salinity, heat, drought, and submergence, thus reducing world rice production [1-4]. At the same time, we must increase global rice production by at least $70 \%$ to feed the anticipated $9.6 \times 10^{9}$ people by $2050[5,6]$. Under these conditions, the improvement of the salinity tolerance of locally grown high-yielding rice cultivars is one of the most promising breeding objectives by which to meet global food demand.

Rice is considered the most salt-sensitive cereal crop [7], with a threshold $\mathrm{EC}_{\mathrm{e}}$ (electrical conductivity of saturated extract) of $3 \mathrm{dSm}^{-1}$, above which yield starts to decline [8-10]. Salinity imposes osmotic effects, ion toxicity, and nutritional imbalance and substantially affects almost all phases of growth $[7,11]$. Possible salt tolerance mechanisms in rice involve ion homeostasis and compartmentalization, ion transport and uptake, biosynthesis and accumulation of osmoprotectants, osmolytes, and compatible solutes, activation of antioxidant enzymes for ROS detoxification, and hormone modulation [12-17]. The Saltol $[18,19]$ and SHOOT $K^{+}$CONCENTRATION $1[20,21]$ genes have been identified from major quantitative trait loci (QTLs) of salt-tolerant landraces Pakkali and Nona Bokra, respectively. These QTLs have been introgressed into some widely grown, high-yielding rice cultivars to improve salt tolerance [22-26], but the rate of improvement is slow.

Rice biotechnology has made advances in identifying single nucleotide polymorphisms (SNPs) controlling salinity tolerance [27-31]. Mutant lines of "Hitomebore" were generated by treatment with ethyl methanesulfonate (EMS), an inducer of nucleotide substitutions, and isolated a salt-tolerant line carrying the hitomebore salt tolerant 1 ( $h s t 1)$ gene. The causative SNP conferring the high salinity tolerance of the hst1 mutant line corresponded to the third exon of the Os06g0183100 gene, which is predicted to encode a B-type response regulator designated OsRR22. We backcrossed the hst1 line with "Hitomebore" to breed the salt-tolerant cultivar "Kaijin", with a yield ability of $5.88 \mathrm{t} \mathrm{ha}^{-1}[32,33]$. "Yukinko-mai" is an early-maturing standard cultivar derived from a cross between "Yukino-sei" and "Domannaka" at the Niigata Agricultural Research Institute's Crop Research Center; it has a high yield potential of $6.84 \mathrm{tha}^{-1}$ [34] and is tolerant to high temperatures during grain filling [35].

To combat earthquake- and tsunami-induced soil salinity in Japan, it is crucial to improve the salt resistance of locally grown popular rice cultivars, most of which are salt sensitive [32,36-38]. In addition, developing Japanese cultivars for international appeal and fine-tuning their yield performance under various ecosystems around the world are time-demanding tasks. To generate new rice cultivars quickly, in response to evolving consumer preferences and crises, we crossed the salt-tolerant "Kaijin" with "Yukinko-mai" to develop a salt-tolerant line with elite agronomic traits through the use of marker-assisted selection (MAS). MAS is the most advanced tool yet developed for the precise introgression of genes of interest into elite rice cultivars [39,40], and allows breeders to recover most of the recurrent parent genome in only two or three generations [41]. Salt, heat, and drought stress-responsive genes or QTLs revealed by recent advances in genomics and biotechnology are being used for MAS of rice all over the world [42-44].

In recent years, rapid generation-advance technology called "speed-breeding" has been used to shorten the generation cycle, accelerating the progress of genomics and breeding studies in multiple crops [45-48]. This technique has been used for the genetical improvement of rice, such as recombinant inbred lines, backcrossed inbred lines, and isogenic cultivars $[46,47]$. The speed breeding method has been reported for six major crops such as spring wheat (Triticum aestivum), durum wheat (Triticum durum), barley (Hordeum vulgare), chickpea (Cicer arietinum), pea (Pisum sativum), and canola (Brassica napus), that uses a prolonged photoperiod to reduce the generation time [48]. Nagatoshi and Fujita [49] developed a breeding technique for short-day soybean plant applying supplemental $\mathrm{CO}_{2}$ in combination with long-day and appropriate temperature cycles. Using speed-breeding, which combines temperature, light duration, and humidity control, tiller removal, and embryo rescue, breeders can obtain four to five advanced generations in a year $[45,46]$. 
In this study, we precisely transferred the hst1 (OsRR22) gene, which confers salinity tolerance, from "Kaijin" into high-yielding "Yukinko-mai" (WT) rice through SNP MAS coupled with speed-breeding. We sequenced the whole genome of a $\mathrm{BC}_{3} \mathrm{~F}_{2} h s t 1$ homozygous line and determined the genome recovery rate. We also examined important physiological and biochemical parameters of the $\mathrm{BC}_{3} \mathrm{~F}_{3}$ generation that confer salt tolerance and evaluated the phenotype under salt stress and normal field conditions.

\section{Results}

\subsection{Breeding Scheme for Development of Advanced Plant Material}

We introgressed the salt-tolerance hst1 gene from "Kaijin" into the genetic background of the high-yielding "Yukinko-mai" by three backcrosses followed by two rounds of self-fertilization (Figure 1A). To accelerate the breeding cycle, we used a biotron speed-breeding system, with controlled temperature and daylength, restriction of tillers, and embryo rescue (Figure S1). At each cross, the plants produced a good quantity of fertilized seed; the cross success rate ranged between $54 \%$ and $69 \%$ (Table S1), and seeds from three or four plants were sufficient to develop new progeny. Each advanced generation took approximately 70 days from germination to flowering and 10 days from pollination to embryo rescue (Figure S1). The total duration of each generation varied according to days to flowering. Using this speed-breeding technique, we developed the $\mathrm{BC}_{3} \mathrm{~F}_{3}$ population, carrying our desired allele in the homozygous state, in six generations and 17 months.
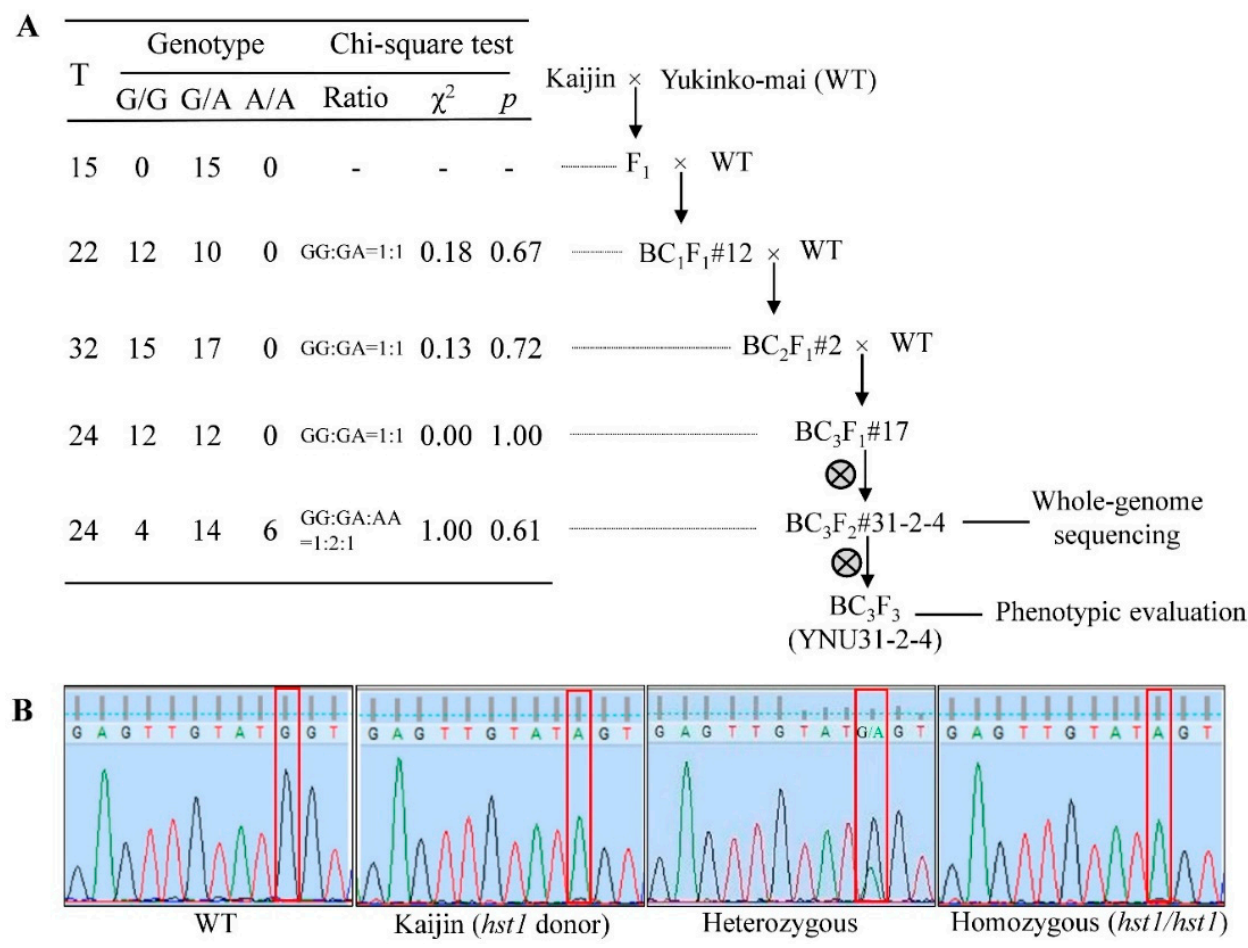

Figure 1. Single nucleotide polymorphism (SNP) marker-aided introgression of hst1 from "Kaijin" into "Yukinko-mai". (A) The hst1 gene was transferred from highly salt-tolerant "Kaijin" into "Yukinko-mai". "Kaijin" was backcrossed to "Yukinko-mai" (WT) 3 times followed by 2 rounds of self-pollination. The table shows the selection results at each generation: $T$, total number of tested plants; $G / G$, number of plants not carrying donor allele; $\mathrm{G} / \mathrm{A}$, number of plants carrying donor allele in heterozygous state; $\mathrm{A} / \mathrm{A}$, plants carrying donor allele in homozygous state. The number after "\#" is the individual plant number used in backcrossing or self-pollination. (B) Advanced breeding individuals were genotyped by direct sequencing. The red box represents nucleotide 1975 of the OsRR22 locus, which is responsible for salt tolerance. 


\subsection{Introgression of hst1 into "Yukinko-mai" (WT) and Genotyping of Advanced Progeny Using SNP Marker}

We used SNP-based genotyping by Sanger sequencing to identify plants harboring the donor allele in each breeding round. A SNP in the OsRR22 (hst1) gene confers the salinity tolerance of the donor parent "Kaijin". The breeding lines were selected on the basis of target peaks of G/A heterozygosity (nucleotide 1975 of the OsRR22 locus) in the $\mathrm{F}_{1}, \mathrm{BC}_{1} \mathrm{~F}_{1}, \mathrm{BC}_{2} \mathrm{~F}_{1}$, and $\mathrm{BC}_{3} \mathrm{~F}_{1}$ generations and of $\mathrm{A} / \mathrm{A}$ homozygosity at the same locus in the $\mathrm{BC}_{3} \mathrm{~F}_{2}$ generation (Figure $1 \mathrm{~B}$ ). In the $\mathrm{F}_{1}$ to $\mathrm{BC}_{3} \mathrm{~F}_{1}$ generations, we obtained two genotypes: either homozygous, lacking the donor allele $(\mathrm{G} / \mathrm{G})$, or heterozygous $(\mathrm{G} / \mathrm{A})$ (Figure $1 \mathrm{~A})$. The heterozygous $\mathrm{BC}_{3} \mathrm{~F}_{1}$ population was self-pollinated to develop $\mathrm{BC}_{3} \mathrm{~F}_{2}$ lines that carried the donor allele in the homozygous state $(\mathrm{A} / \mathrm{A}) . \mathrm{BC}_{3} \mathrm{~F}_{2}$ plants $(\mathrm{A} / \mathrm{A})$ morphologically similar to the recurrent parent were self-pollinated to develop the $\mathrm{BC}_{3} \mathrm{~F}_{3}$ generation. We sequenced the whole genome of the $\mathrm{BC}_{3} \mathrm{~F}_{2}$ line \#31-2-4 to compare it with the parental genome, and characterized it.

\subsection{Recovery Rate and Characterization of $B_{3} \mathrm{~F}_{2} \# 31-2-4$ Genome}

To investigate the genetic similarities between our advanced line and the parents, we analyzed $\mathrm{BC}_{3} \mathrm{~F}_{2} \# 31-2-4$ using whole-genome sequencing. After we filtered out low-reliability SNPs/indels, \#31-2-4 showed 118454 SNPs/indels, comprising 106288 "Yukinko-mai"-type homozygous alleles, 3157 "Kaijin"-type homozygous alleles, and 9009 heterozygous alleles (Table 1). These SNPs/indels lie across the genome with deep coverage (Figure 2, dots), indicating high resolution and successful genome-wide genotyping. Allele types formed dense blocks on chromosomes (Figure 2, vertical bars), clearly showing recovered regions ("Yukinko-mai" homozygous blocks), "Kaijin" genome segments ("Kaijin" homozygous blocks), and unfixed segments (heterozygous blocks) (Figure 2, horizontal bar). "Yukinko-mai" chromosomes (Chrs.) 5, 11, and 12 were recovered almost completely. There were small "Kaijin" segments in Chrs. 1, 4, 7, 9, and 10, large "Kaijin" segments in Chrs. 2, 3, and 6, small heterozygous segments in Chr. 4, and large heterozygous segments in Chrs. 3, 6, 8, and 9. Interestingly, we identified some genotype blocks overlapping other genotype blocks (Figure 2, chr08, 5-10 Mb; chr09, 10-12 Mb), resulting from continuous recombination events in these extremely short regions [50,51]. We calculated the genome recovery rate from the number of "Yukinko-mai" alleles out of the total number; the $\mathrm{BC}_{3} \mathrm{~F}_{2}$ genome recovered $93.5 \%$ of the "Yukinko-mai" genome, from $89.7 \%$ homozygous alleles and 7.6\% heterozygous alleles (Table 1; Section 4.7). This score is close to the theoretical value of $93.7 \%$ following three backcrosses and one self-fertilization. In addition, $2.7 \%$ of the $\mathrm{BC}_{3} \mathrm{~F}_{2}$ genome was "Kaijin" homozygous and $7.6 \%$ remained unfixed as heterozygous (Table 1).

Table 1. Single nucleotide polymorphism (SNP)/indel detection in $\mathrm{BC}_{3} \mathrm{~F}_{2} \# 31-2-4$. SNPs/indels in $\mathrm{BC}_{3} \mathrm{~F}_{2}$ \#31-2-4 are classified into "Yukinko-mai"-type (homo[zygous]), “Kaijin"-type (homo(zygous)), and Hetero(zygous) alleles.

\begin{tabular}{ccccc}
\hline \multirow{2}{*}{ Genotype } & \multicolumn{3}{c}{ Number of Variants } & \multirow{2}{*}{ Genome \% } \\
\cline { 2 - 4 } & SNPs & Indels & Total & \\
\hline 'Yukinko-mai" & 84927 & 21361 & 106288 & 89.7 \\
(homo) & 2329 & 828 & 3157 & 2.7 \\
"Kaijin" (homo) & 7556 & 1453 & 9009 & 7.6 \\
Hetero & 94812 & 23642 & 118454 & 100.0 \\
Total & & & & \\
\hline
\end{tabular}

To estimate the effects of variants on phenotypes, we listed variants causing protein sequence alterations (e.g., frameshift and in-frame indels, non-synonymous SNPs, SNPs/indels at splice donor/acceptor sites etc.) in SnpEff software for Sequence Ontology and effect prediction (Figure 3). In $\mathrm{BC}_{3} \mathrm{~F}_{2}, 207$ "Kaijin" homozygous and 536 heterozygous variants were found in exon and splice sites. Only 71 and 230, respectively, of those caused protein sequence alterations (Figure 3; Table S2). These non-synonymous changes occurred in only four genes for agronomic traits (Table 2). 

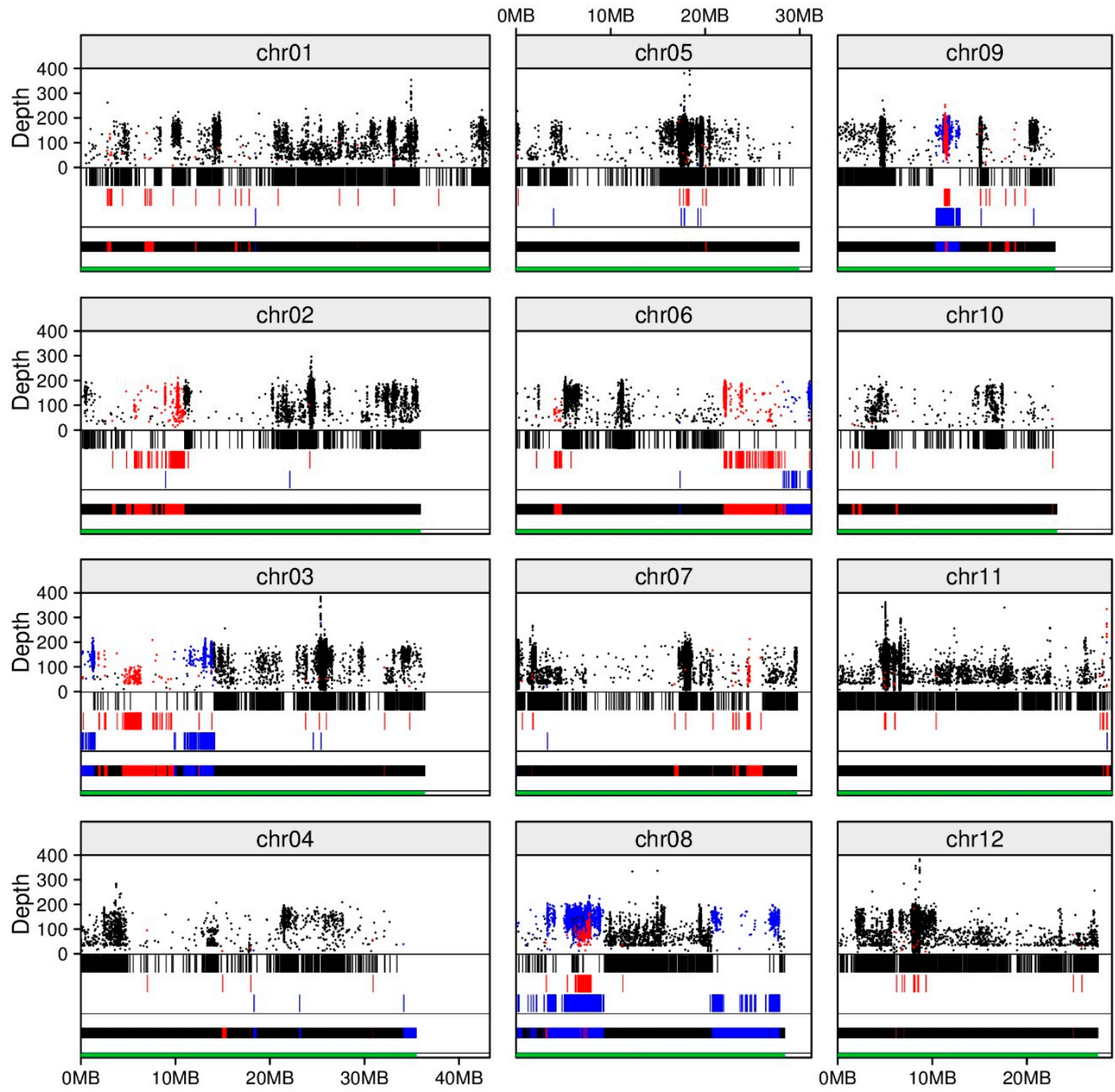

SNPs/INDELs positions

Figure 2. Positions and depths of SNPs/indels and genotype blocks on $\mathrm{BC}_{3} \mathrm{~F}_{2} \# 31-2-4$ genome. Dots show coverage depth of SNPs/indels. Vertical bars show their positions by genotype (color). Horizontal bar shows densities of SNPs/indels densities in 10,000-nt sliding window by genotype (colour). Black, "Yukinko-mai"-type homozygous; red, "Kaijin"-type homozygous; blue, heterozygous. Green bars represent chromosome length.

\subsection{Field Evaluation of the "YNU31-2-4" for Main Agronomic Traits}

We evaluated "YNU31-2-4" in the field to compare its major agronomic traits with those of the parents. We found a significant difference in days-to-heading between "YNU31-2-4" and WT: some plants headed significantly earlier than WT (Table 3; Figure S2B). Heading date was associated negatively with the Os09g0356200 genotype and positively with the $h s t 1$ genotype. These results support the accuracy of gene-based GWAS [53], and also suggest the potential early flowering function of $h s t 1$ or the effect of unknown flowering-related genes. Grain width, grain thickness, and 1000-grain weight were significantly higher in "YNU31-2-4" plants than WT (Table 3). The hst1 mutant also had a wider grain than WT [32]. Together these results, at least partly, suggest that $h s t 1$ might be involved in the increase of grain width. In contrast, other important morphological traits of "YNU31-2-4" were highly similar to those of WT, particularly flag leaf color, length, and width, plant height, tiller number 
per plant, panicle number per plant, panicle length, spikelet number per panicle, grain yield per plant, aboveground biomass per plant, and grain length (Table 3; Figure S3A-C).
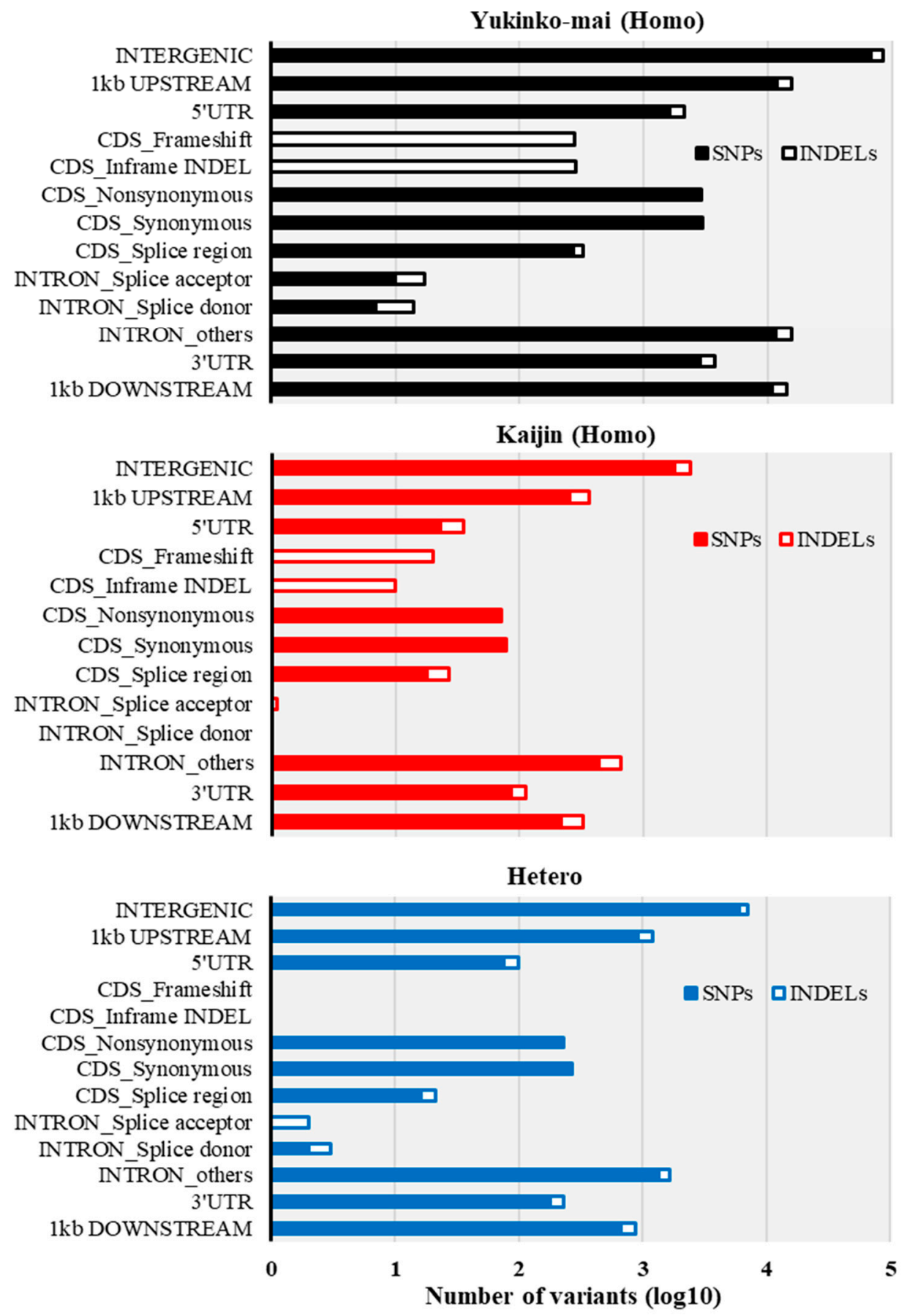

Figure 3. Sequence Ontology analysis of $\mathrm{BC}_{3} \mathrm{~F}_{2} \mathrm{SNPs} /$ indels. Sequence Ontology is based on SnpEff terms with minor modifications. Closed bars, SNPs; open bars, indels. Black, "Yukinko-mai"-type homozygous, red, "Kaijin"-type homozygous; blue, heterozygous. 
Table 2. List of agronomic-trait-related genes harboring alternative protein sequences in $\mathrm{BC}_{3} \mathrm{~F}_{2} \# 31-2-4$. Chr., chromosome; Ref., Nipponbare reference allele; Hetero, heterozygous. Dataset 1, Overview of Functionally Characterized Genes in Rice Online database (OGRO) [52]; Dataset 2, potential agronomic functional gene set by gene-based GWAS of Japanese rice population [53].

\begin{tabular}{|c|c|c|c|c|c|c|c|c|c|}
\hline \multirow{2}{*}{ Chr./Position } & \multirow{2}{*}{ Ref. SNP/Indel } & \multicolumn{3}{|c|}{ Genotype } & \multirow[b]{2}{*}{ Alteration Type } & \multirow[b]{2}{*}{ RAP ID } & \multirow[b]{2}{*}{ Protein Encoded } & \multirow[b]{2}{*}{ Dataset 1} & \multirow[b]{2}{*}{ Dataset 2} \\
\hline & & $\mathrm{BC}_{3} \mathrm{~F}_{2}$ & “Kaijin" & "Yukinko-mai" & & & & & \\
\hline Chr06/26277010 & G & A & A & G & missense SNP & Os06g0644200 & $\begin{array}{l}\text { Vacuolar HD-translocating inorganic } \\
\text { pyrophosphatase } 1\end{array}$ & Cold tolerance & - \\
\hline Chr08/6268486 & GCACGGCCACGGC & Hetero & GCACGGCCACGGC & G & in-frame deletion & Os08g0207500 & $\begin{array}{l}\text { Zn-regulated transporter, iron } \\
\text { (Fe)-regulated transporter-like protein } 4\end{array}$ & $\begin{array}{l}\text { Other soil stress } \\
\text { tolerance }\end{array}$ & - \\
\hline Chr08/26913261 & G & Hetero & G & A & missense SNP & Os08g0538300 & Chitin elicitor receptor kinase 1 & Blast resistance & - \\
\hline Chr09/11449688 & G & Hetero & G & A & missense SNP & Os09g0356200 & Malectin-like carbohydrate-binding & - & Days to \\
\hline Chr09/11449800 & AGG & Hetero & AGG & $\mathrm{AC}$ & frameshift deletion & Usugg0356200 & domain-containing protein & - & heading \\
\hline
\end{tabular}


Table 3. Growth and yield performance of "Kaijin", WT, and "YNU31-2-4" genotypes under normal field conditions. Grain yield is weight of filled spikelets at $14 \%$ moisture content. Data are mean \pm SD $(n=10-12)$. Values with the same letter within a row are not statistically different (Duncan's multiple range test, $p<0.05)$.

\begin{tabular}{cccc}
\hline Agronomic Traits & \multicolumn{3}{c}{ Genotype } \\
\cline { 2 - 4 } & "Kaijin" & WT & "YNU31-2-4" \\
\hline Flag leaf greenness (SPAD value) & $42.93 \pm 2.63 \mathrm{a}$ & $43.49 \pm 1.82 \mathrm{a}$ & $43.24 \pm 2.42 \mathrm{a}$ \\
Flag leaf length (cm) & $27.21 \pm 2.53 \mathrm{~b}$ & $29.85 \pm 2.13 \mathrm{a}$ & $29.12 \pm 1.85 \mathrm{a}$ \\
Flag leaf width (cm) & $1.11 \pm 0.06 \mathrm{~b}$ & $1.23 \pm 0.10 \mathrm{a}$ & $1.21 \pm 0.04 \mathrm{a}$ \\
Days-to-heading (day) & $105.17 \pm 1.40 \mathrm{a}$ & $105.08 \pm 1.38 \mathrm{a}$ & $103.75 \pm 1.76 \mathrm{~b}$ \\
Plant height (cm) & $98.42 \pm 3.56 \mathrm{a}$ & $94.75 \pm 3.49 \mathrm{~b}$ & $95.83 \pm 2.41 \mathrm{ab}$ \\
Tiller number per plant & $20.40 \pm 3.31 \mathrm{~b}$ & $23.80 \pm 3.22 \mathrm{a}$ & $24.40 \pm 3.57 \mathrm{a}$ \\
Panicle number per plant & $20.40 \pm 3.31 \mathrm{~b}$ & $23.80 \pm 3.22 \mathrm{a}$ & $24.20 \pm 3.12 \mathrm{a}$ \\
Panicle length (cm) & $18.71 \pm 0.69 \mathrm{~b}$ & $19.79 \pm 0.52 \mathrm{a}$ & $19.11 \pm 0.97 \mathrm{ab}$ \\
Spikelet number per panicle & $71.99 \pm 8.91 \mathrm{a}$ & $73.55 \pm 6.27 \mathrm{a}$ & $72.66 \pm 5.80 \mathrm{a}$ \\
Grain number per panicle & $63.61 \pm 8.20 \mathrm{a}$ & $67.36 \pm 5.81 \mathrm{a}$ & $60.59 \pm 7.29 \mathrm{a}$ \\
1000-grain weight (g) & $22.42 \pm 0.14 \mathrm{~b}$ & $21.56 \pm 0.22 \mathrm{c}$ & $23.29 \pm 0.43 \mathrm{a}$ \\
Seed setting rate (\%) & $88.34 \pm 3.71 \mathrm{a}$ & $91.61 \pm 2.52 \mathrm{a}$ & $83.43 \pm 7.58 \mathrm{~b}$ \\
Grain yield (g per plant) & $33.77 \pm 4.24 \mathrm{~b}$ & $40.07 \pm 4.59 \mathrm{a}$ & $37.84 \pm 4.46 \mathrm{a}$ \\
Aboveground biomass (g per plant) & $61.80 \pm 8.50 \mathrm{~b}$ & $72.30 \pm 7.63 \mathrm{a}$ & $67.13 \pm 9.14 \mathrm{ab}$ \\
Grain length (mm) & $5.05 \pm 0.03 \mathrm{~b}$ & $5.17 \pm 0.01 \mathrm{a}$ & $5.21 \pm 0.06 \mathrm{a}$ \\
Grain width (mm) & $2.78 \pm 0.01 \mathrm{~b}$ & $2.66 \pm 0.01 \mathrm{c}$ & $2.86 \pm 0.04 \mathrm{a}$ \\
Grain thickness (mm) & $2.14 \pm 0.01 \mathrm{a}$ & $2.07 \pm 0.01 \mathrm{c}$ & $2.10 \pm 0.01 \mathrm{~b}$ \\
\hline
\end{tabular}

\subsection{Salinity Tolerance of the "YNU31-2-4" Line at Seedling Stage}

We evaluated the salinity tolerance of "Kaijin", "Yukinko-mai" (WT), and "YNU31-2-4" seedlings during three weeks at 0,75 , and $125 \mathrm{mM} \mathrm{NaCl}$. At $0 \mathrm{mM} \mathrm{NaCl}$, there was no phenotypic difference between "YNU31-2-4" and WT (Figure 4A). Under salt stress, however, the WT leaves were rolled, whereas those of "Kaijin" and "YNU31-2-4" remained flat and stayed green even at $125 \mathrm{mM} \mathrm{NaCl}$. Further, $125 \mathrm{mM} \mathrm{NaCl}$ reduced the survival of WT seedlings to $52.5 \%$, whereas all seedlings of "YNU31-2-4" survived (Figure 4B). Moreover, "Kaijin" and "YNU31-2-4" had better shoot and root growth under salinity vs. WT (Figure 4C-F); at $125 \mathrm{mM} \mathrm{NaCl}$, "YNU31-2-4" had 30\% and 38\% better shoot and root dry weight, respectively than WT. In a separate experiment (Figure S4), at $0 \mathrm{mM} \mathrm{NaCl}$, there were no significant differences in leaf relative water content or chlorophyll content between WT and "YNU31-2-4" plants. Under salt stress, the "YNU31-2-4" plants were able to maintain significantly higher relative water content and chlorophyll levels than WT (Figure S4A,B). Under the control condition, "YNU31-2-4" had significantly higher proline content than the parents. Exposure to salinity led to a considerable increase in proline levels in all genotypes, and to $1.6 \times$ the WT level in "YNU31-2-4" (Figure S4C). These results clearly indicate that "YNU31-2-4" has stronger salt tolerance than "Yukinko-mai" (WT) at the seedling stage.

\section{6. $\mathrm{Na}^{+}$and $\mathrm{K}^{+}$Content in Shoot and Roots of the Tested Genotypes under Salt Stress}

We assayed the $\mathrm{K}^{+}$and $\mathrm{Na}^{+}$contents in shoots and roots of seedlings under salinity, since the degree of stress depends on their uptake and translocation. Under control condition, shoot $\mathrm{K}^{+}$was significantly lower in "YNU31-2-4" than in its parent (Figure 5A), whereas under salt stress, it was 1.4X the WT level in shoot and 2.6× in root (Figure 5A,D). Under control condition, $\mathrm{Na}^{+}$levels in leaves (Figure 5B) and roots (Figure 5E) of all genotypes remained similarly low. Salinity stress increased $\mathrm{Na}^{+}$ concentration in WT shoots relative to the other two genotypes, reaching $6.5 \times$ that in "YNU31-2-4" plants (Figure $5 \mathrm{~B}$ ). Under control conditions, the $\mathrm{Na}^{+} / \mathrm{K}^{+}$ratio did not differ significantly among the tested genotypes in shoots (Figure 5C) and roots (Figure 5F). Under salinity, it was 9.2× the "YNU31-2-4" level in WT shoots and 2.9× in WT roots (Figure 5C,F). 


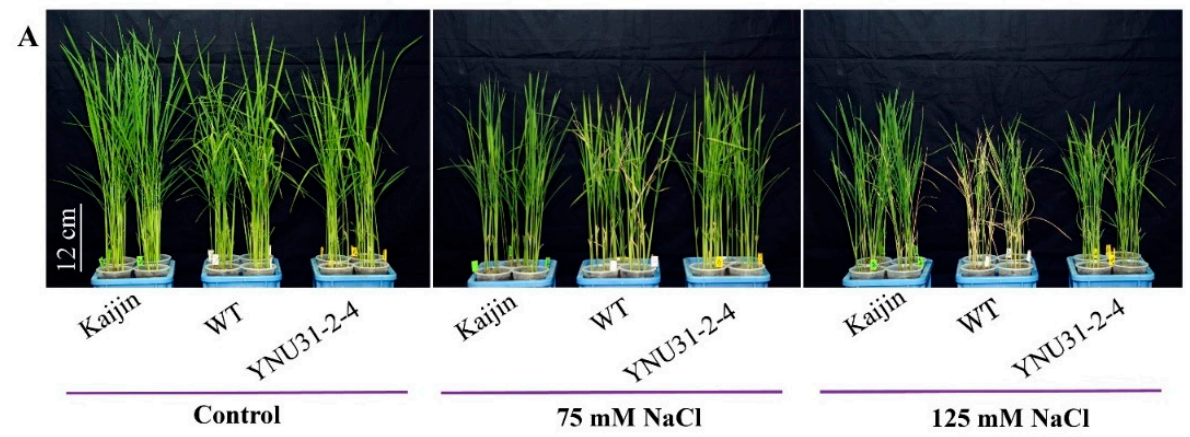

B

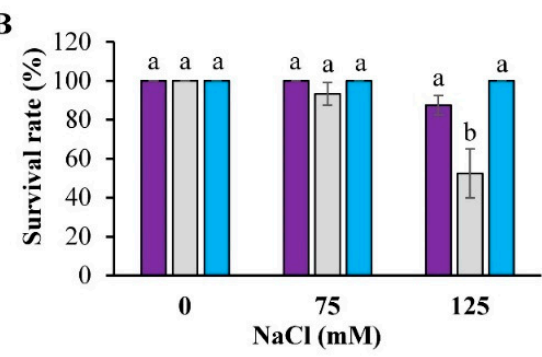

D

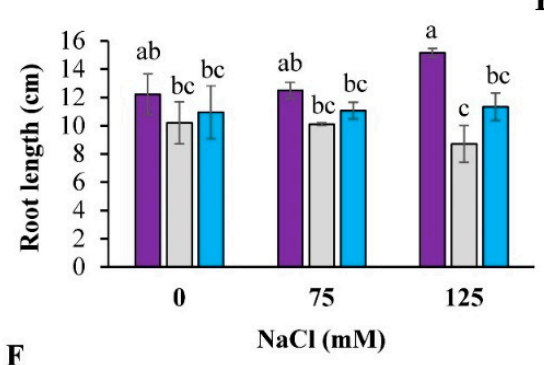

F

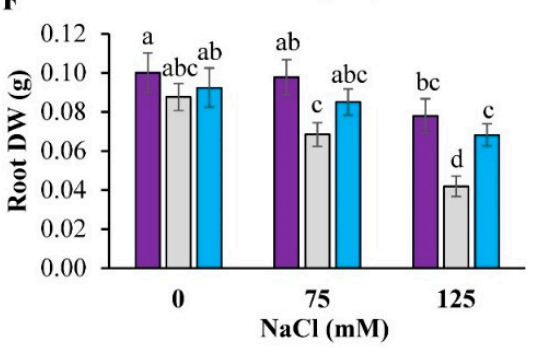

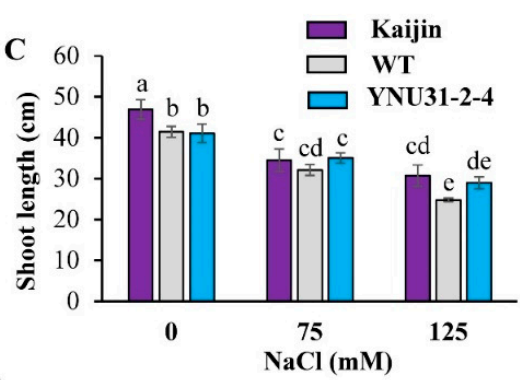

$\mathbf{E}$

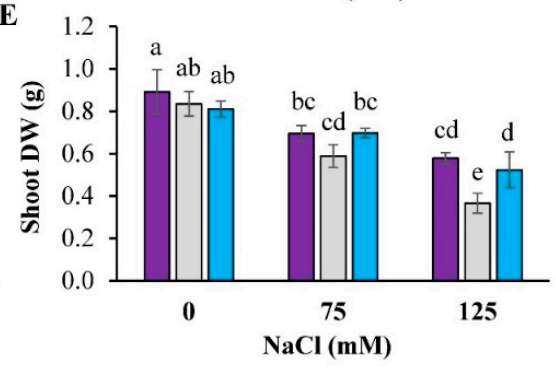

Figure 4. Salinity tolerance of $\mathrm{BC}_{3} \mathrm{~F}_{3}$ line "YNU31-2-4" at seedling stage. (A) Phenotypic comparison of "Kaijin", WT, and "YNU31-2-4" seedlings grown in 0, 75, or $125 \mathrm{mM} \mathrm{NaCl}$ for two weeks. (B) Survival rates, (C) shoot length, (D) root length, (E) shoot dry weight, and (F) root dry weight of seedlings shown in A. Data in B-F are mean \pm SD of four independent biological replicates; data in $\mathbf{E}$ and $\mathbf{F}$ are dry weight (DW) of 10 plants in each treatment. Bars labeled with the same letter are not statistically different (Tukey's test, $p<0.05$ ).

Under the control condition, electron probe microanalysis revealed a dense distribution of $\mathrm{K}^{+}$in the basal portion of the shoot of all genotypes, but only a very sparse distribution of $\mathrm{Na}^{+}$(Figure 6). Under salt stress, the $\mathrm{Na}^{+}$distribution in cells was increased in all genotypes, and the salt-sensitive WT accumulated significantly more $\mathrm{Na}^{+}$than the other two genotypes (Figure 6).

\subsection{Salinity Tolerance and Yield Assessment at Reproductive Stage}

Under control condition at the reproductive stage, there was no obvious phenotypic difference between WT and "YNU31-2-4" plants (Figure 7A). Salt stress for five weeks caused severe burning and wilting symptoms in WT, but "YNU31-2-4" and "Kaijin" plants maintained green leaves. Under control condition, the penultimate leaves of "YNU31-2-4" plants maintained a slightly higher net $\mathrm{CO}_{2}$ 
assimilation rate than the parents (Figure 7B). Salt stress for four weeks significantly reduced the net $\mathrm{CO}_{2}$ assimilation rate of WT plants relative to "YNU31-2-4" and "Kaijin". Under the control condition, WT and "YNU31-2-4" plants had similar phenotypic characters and yield attributes except for a higher 1000-spikelet weight than the parents (Figure 7C-G). Under salt stress, in contrast, "YNU31-2-4" had higher plant height, yield characters, and aboveground biomass than WT (Figure 7C-G,I). Relative to control condition, salt stress reduced grain yield by $68 \%$ in WT but by $38 \%$ in "YNU31-2-4" (Figure 7H). As a result, the grain yield of "YNU31-2-4" was 10\% higher than that of the donor parent "Kaijin" under control condition and $45 \%$ higher than that of WT under saline condition.
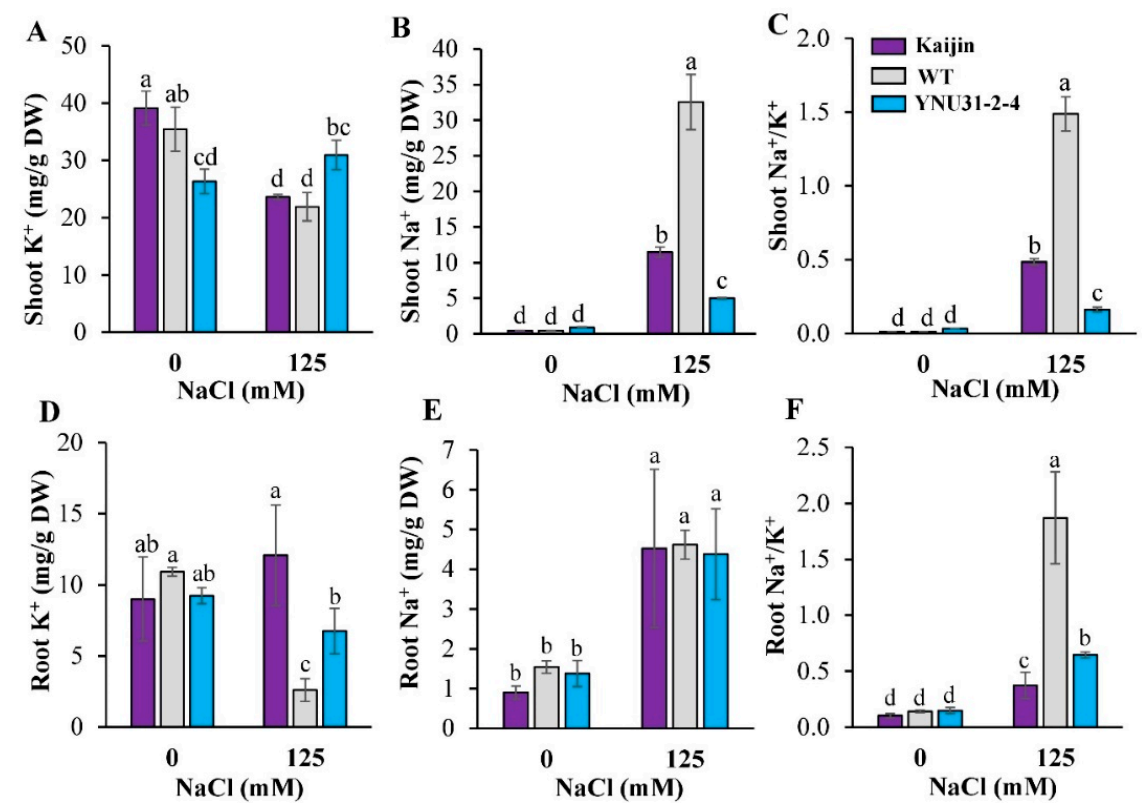

Figure 5. $\mathrm{Na}^{+}$and $\mathrm{K}^{+}$content in shoot and roots of the tested genotypes under salt stress. (A) Shoot $\mathrm{K}^{+},\left(\right.$B) shoot $\mathrm{Na}^{+}$, (C) shoot $\mathrm{Na}^{+} / \mathrm{K}^{+}$, (D) $\operatorname{root} \mathrm{K}^{+},(\mathrm{E}) \operatorname{root} \mathrm{Na}^{+}$, and (F) $\operatorname{root} \mathrm{Na}^{+} / \mathrm{K}^{+}$of 20 -day-old seedlings. Data are mean \pm SD of three independent biological replicates. Bars with the same letter are not statistically different (Duncan's multiple range test, $p<0.05$ ).
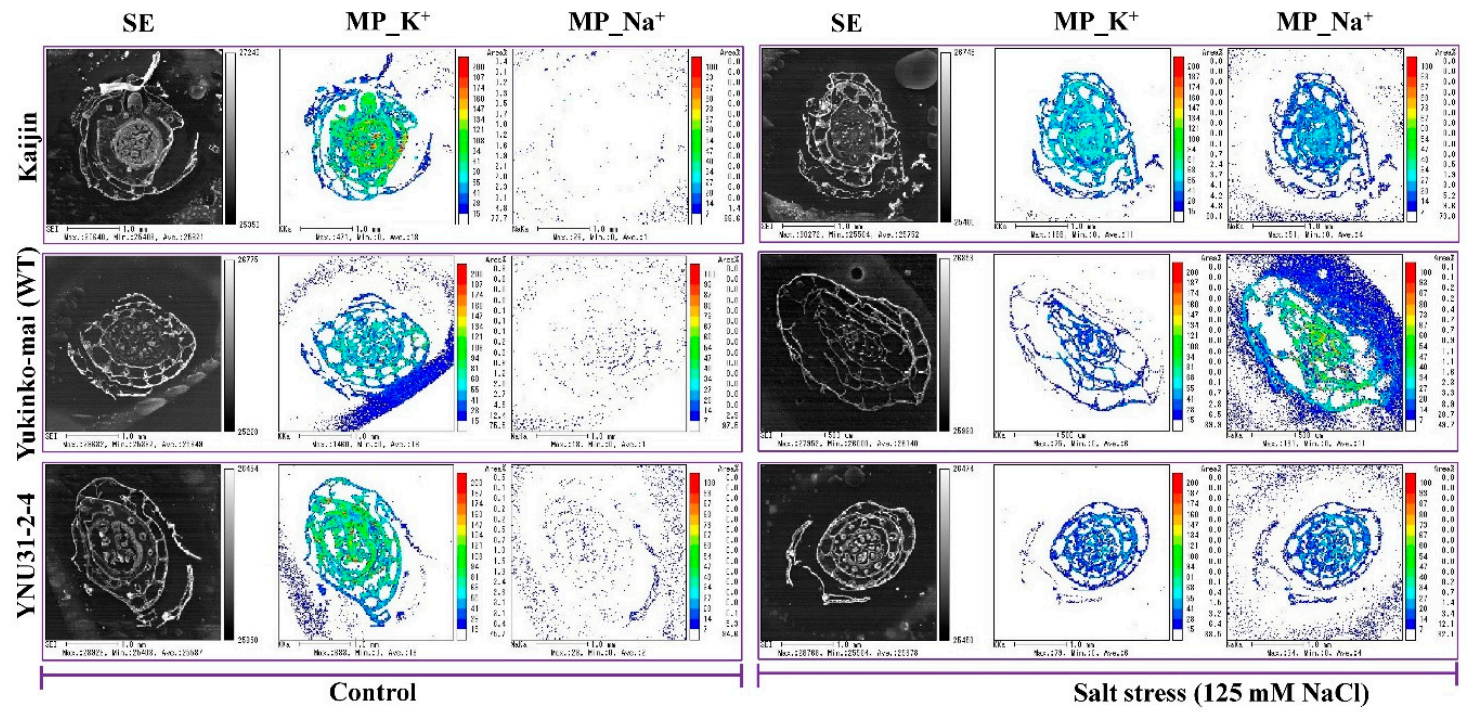

Figure 6. Accumulation and distribution of $\mathrm{K}^{+}$and $\mathrm{Na}^{+}$in cell clusters of 20-day-old seedlings. Relative amounts of $\mathrm{K}^{+}$and $\mathrm{Na}^{+}$are indicated by color coding. SE, secondary electron image; MP_K ${ }^{+}$, mapping pattern of $\mathrm{K}^{+}$; $\mathrm{MP} \_\mathrm{Na}^{+}$, mapping pattern of $\mathrm{Na}^{+}$. 
A
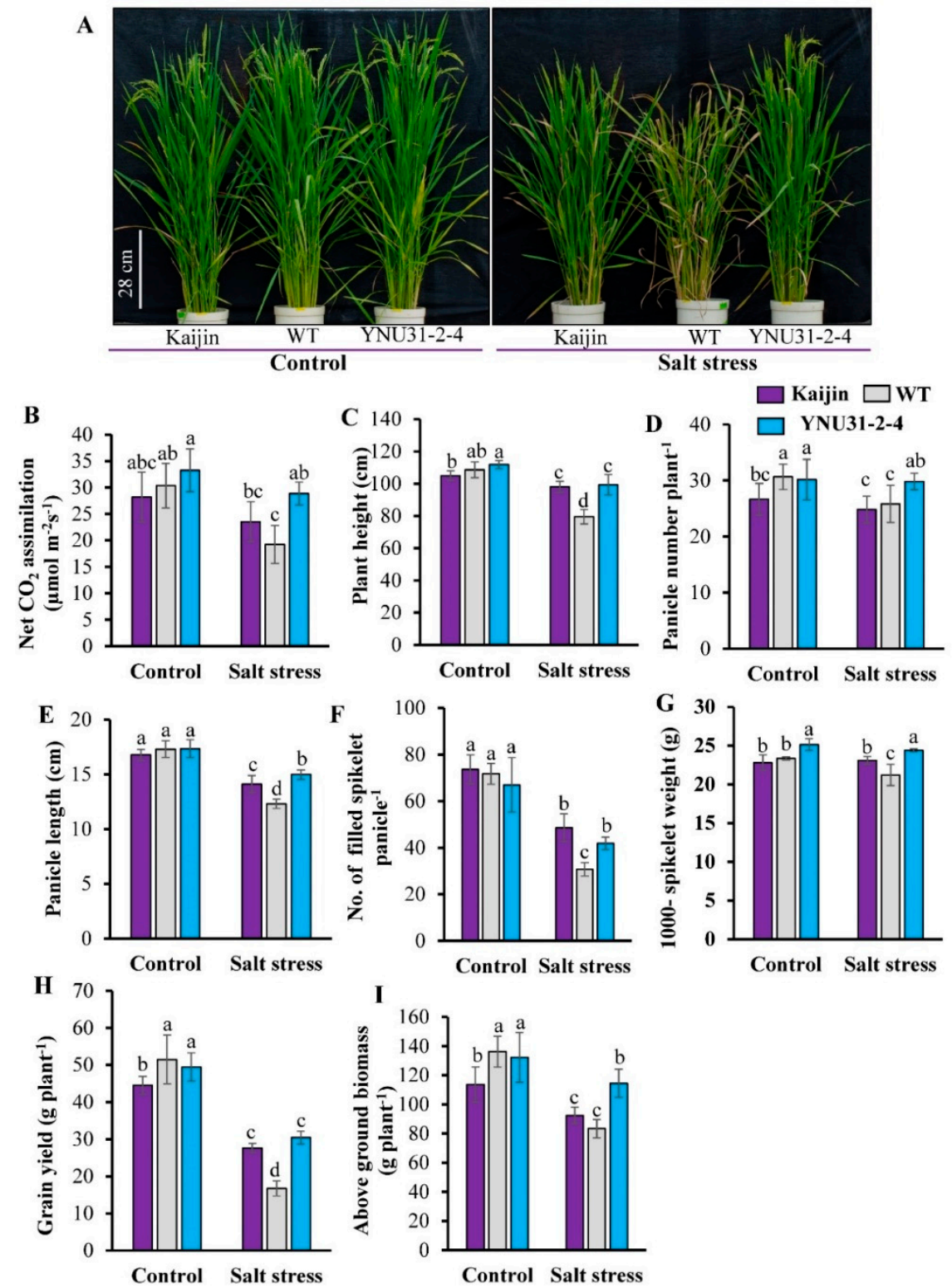

Figure 7. Salinity tolerance of $\mathrm{BC}_{3} \mathrm{~F}_{3}$ line "YNU31-2-4" at heading. (A) Phenotypic comparison of "Kaijin", WT, and "YNU31-2-4" plants grown with or without salt stress. Salt-stressed plants were grown in $50 \mathrm{mM} \mathrm{NaCl}$ from 60 days after germination (DAG) and then in $75 \mathrm{mM}$ from 74 DAG until 95 DAG (booting stage), and then in fresh water until 110 DAG (heading). (B) Net $\mathrm{CO}_{2}$ assimilation rate of the penultimate leaf four weeks after imposition of salt treatment. (C) Comparison of plant height at 110 DAG. (D-I) Comparisons of (D) number of panicles/plant, (E) panicle length, (F) number of filled spikelets/panicle, (G) weight of 1000 filled spikelets, (H) grain yield/plant, and (I) dry weight of aboveground biomass at harvest. Data are mean \pm SD of 6 individuals. Bars with the same letter are not statistically different (Duncan's multiple range test, $p<0.05$ ).

\section{Discussion}

Soil salinity is a major threat to the future food production, affecting more than $6 \%$ of the total land area [54]. The rapid global warming and sea level rise pose threats to rice yield and quality in South Asian rice-growing countries. In addition, a tsunami contaminated paddy field in Miyagi prefecture, Japan, with salt in 2011 [32,37,55]. Therefore, it is important to introgress genes/QTLs/SNPs conferring salt tolerance in locally grown popular rice cultivars, focusing on higher grain yield, to ensure food security under changing climatic conditions. Cultivar improvement through conventional breeding 
is feasible, but it takes a long time to minimize linkage drag through phenotypic screening [56,57]. For these reasons and to achieve breeding goals, we introgressed the hst1 gene from "Kaijin" into "Yukinko-mai", which has excellent yield stability. We developed the $\mathrm{BC}_{3} \mathrm{~F}_{3}$ generation, named "YNU31-2-4", through SNP marker-assisted selection (Figure 1A).

To accelerate the breeding cycle, we used a biotron speed-breeding system (Figure S1) without a $\mathrm{CO}_{2}$ supply, since the application of $475 \mathrm{ppm} \mathrm{CO}_{2}$ in growth chambers did not greatly change the breeding cycle [45], and many rice breeders do not have $\mathrm{CO}_{2}$ regulation facilities owing to the high cost. By using a longer daylength (14/10 h light/dark) for first 30 days to accelerate the vegetative growth followed by a shorter daylength (10/14 h light/dark) to induce reproduction, tiller removal, and embryo rescue to decrease the period before seed maturity (Figure S1), we were able to achieve four breeding generations within 11 months (Table S1). Developing four to five generations a year is the ultimate objective [46-48]. This simplified, faster, efficient method for reducing the duration and number of breeding cycles will contribute significantly to genomic studies and the deployment of superior rice.

We used whole-genome sequencing (WGS) to characterize the advanced breeding lines and revealed genome recovery rate, genotype blocks, and putative phenotypes (Figures 2 and 3; Tables 1 and 2). WGS identified 118454 SNPs/indels as markers. As WGS provides higher resolution of genome blocks than conventional SSR marker methods [58], it can thus be used for advancing generations from parents with low genetic variation, as here. Furthermore, in subsequent selection, knowledge of these genotype blocks helped us to rapidly fix heterozygous regions into the recipient allele through the MABC selection method (Figure S2A). Our high-resolution analysis with massive numbers of $\mathrm{SNP} /$ indel markers not only enabled accurate genome-wide genotyping, but also highlighted potential recombination hotspots.

Functional annotation was able to predict five SNP/indels (Table 2) that may affect agronomic traits and thus phenotype in our advanced line "YNU31-2-4". One of two non-synonymous changes in Os09g0356200, a putative heading-date-associated gene identified in a gene-based genome-wide association study (GWAS) [53], caused a frameshift deletion probably causing loss-of-function. $\mathrm{BC}_{3} \mathrm{~F}_{3}$ progeny of $\mathrm{BC}_{3} \mathrm{~F}_{2}$ plants harboring the $O s 09 g 0356200$ gene in the heterozygous state likely shows a wide range of heading date. Indeed, the field assessment results demonstrate the difference in the distribution of heading dates between "YNU31-2-4" and WT ("Yukinko-mai") (Table 3; Figure S2B). Additionally, the heading date of the $\mathrm{BC}_{3} \mathrm{~F}_{3}$ population was associated with the genotype of the putative heading-date-associated gene Os09g0356200 (Table 2; Figure S2). Our finding indicates the potential value and reliability of gene-based GWAS among the Japanese rice population data set [53] in breeding by incorporating the genetic variations into those cultivars, and its practical value in predicting genes governing complex traits of agronomic phenotypes. The results of whole-genome sequencing have demonstrated the success in developing improved cultivars using our rapid breeding system. They also reveal undesirable genome regions and genes from the donor parent "Kaijin", valuable information for estimating agronomic properties without further phenotyping study. Identifying heterozygous genes can provide mechanistic insights toward homogenizing phenotypes for ongoing breeding. It is important to note that the heterozygote disadvantage has been overcome by taking advantage of the SNP-based selection of the homozygous WT allele from the YNU31-2-4 population (Figure S2). Furthermore, other morphological traits of "YNU31-2-4" were similar to those of WT (Table 3; Figure $\mathrm{S} 3 \mathrm{~A}-\mathrm{C}$ ). The field assessment results along with the high-resolution genotyping data indicate no apparent grain yield reduction in "YNU31-2-4" in relation to the presence of the target $h s t 1$ gene. In fact, "YNU31-2-4" increased ca. 11\% yield than the donor parent "Kaijin" owing to the higher number of panicles per plant and 1000-grain weight.

Rice is very sensitive to salt stress at the seedling stage [7], and its sensitivity varies with the developmental stage [59]. To assess the practical utility of $h s t 1$ in our introgression line, we exposed seedlings to moderate $(75 \mathrm{mM})$ and high $(125 \mathrm{mM})$ salt stresses. Salt tolerance at this stage is of importance in saline environments, as crop establishment is fundamentally determined during the earliest stages of development. Our findings revealed that under high salt stress, the "YNU31-2-4" 
plants had a significantly higher survival rate, shoot, and root biomass than WT (Figure 4A-F), which suggest strong tolerance similar to that of the donor parent. The "YNU31-2-4" plants maintained significantly higher plant growth, proline content, and plant water status under salinity, which could indicate a physiological and biochemical tolerance mechanism $[54,60]$. In fact, previous studies showed that salinity might reduce the fertility of the spike and the translocation of assimilates to the grain in bread wheat and rice. Physiologically, the "YNU31-2-4" maintain its fully hydrated state under saline condition, which could at least partially have rapid and large effects on cell expansion, cell division, stomatal opening, maintain normal rates of transpiration, abscisic acid (ABA) accumulation, etc. Assay of soluble proline levels is a useful way to monitor physiological status and to assess stress tolerance, since plants under salt stress accumulate this osmoprotectant against ion-dependent protein degradation [61]. Proline is accumulated in taxonomically diverse sets of plants [62], providing stress tolerance by protecting the cell membrane and maintaining osmotic balance within the cell, and also serves as an organic nitrogen reserve during stress recovery $[61,63,64]$.

We also assessed yield traits of "YNU31-2-4" under salt stress at the early reproductive to booting stages, when salt stress reduces panicle and spikelet numbers per plant, leading to significant yield losses $[65,66]$. The improvement of rice grain yield under salt stress is the focus of breeding [67]. Owing to the significant increases in panicle number per plant, spikelet number per panicle, and 1000-spikelet weight, the final grain yield of "YNU31-2-4" plants was $45 \%$ higher than WT under salt stress at the reproductive stage (Figure 7D,F-H). Under control condition, there was no yield difference between "YNU31-2-4" and WT (Figure 7H). Interestingly, "YNU31-2-4" has higher yield potential than the donor parent under control condition owing to the higher number of panicles per plant and 1000-spikelet weight, comparable to the field evaluation results (Figure 7D, G). The higher number of panicles can be attributable to the WT background. The higher seed weight of "YNU31-2-4" could be due, at least partly, to the improved photosynthetic efficiency (Figure 7B) due to coordination of leaf morphological (Table 3) and physiological (Figure 7B; Figure S4) traits, which has great potential for use in breeding for higher yield. Accordingly, "YNU31-2-4" showed larger flag leaf than the donor "Kaijin", which could play an important role to grain filling and hence determining yield potential. The superior tiller growth with higher leaf size rendered the source, sink, and flow stronger and more harmonized and consequently increased the cereal yield [68-72]. Thus, this study clearly shows that the introgression of $h s t 1$ to the WT significantly increased salt resistance without any reduction in grain yield. Thus, "YNU31-2-4" has significant breeding value without a noticeable yield penalty under normal and salt stress conditions.

Roots absorb minerals and water from the soil and play a key role in transporting them to leaves. In the context of salt tolerance, roots are sensitive to $\mathrm{NaCl}$ and are the first site of defense, directly limiting or excluding sodium uptake $[54,73]$. Roots are often used as a biomarker of salt stress. Root architecture differed between WT and "YNU31-2-4" plants after two weeks of normal hydroponic culture (Figure S5). Roots of "YNU31-2-4" and "Kaijin" exposed to high salt stress elongated more than WT roots (Figure 4D). The better morphophysiological and biochemical characters of "YNU31-2-4" under salt stress demonstrate the success of introgression of $h s t 1$ into "Yukinko-mai".

The genes involved in conferring salt tolerance, which is likely a complex trait controlled by a combination of multiple genes, are yet to be elucidated. Recent research advances have identified major genes conferring salinity tolerance in rice, including OsHKT1;1, OsHKT2;1, OsSOS1, OsNHX1, OsCAX1, OsAKT1, OsKCO1, OsNRT1;2, OsCLC1, OsADS31 and OsTPC1; however, their functional pathways during salt stress are not coordinately linked for explaining the very complex phenomenon of salt tolerance $[16,74,75]$. The $h s t 1$ (loss-of-function in OsRR22) gene primarily led to the upregulation of OsHKT1;1 (encoding a high-affinity $\mathrm{K}^{+}$transporter) that functions as a $\mathrm{Na}^{+}$transporter contributing salt resistance of the $h s t 1$ mutant and "Kaijin" [32]. In our experiment, $\mathrm{Na}^{+}$content and $\mathrm{Na}^{+} / \mathrm{K}^{+}$ratio in leaf and root were divergent between WT and "YNU31-2-4" and therefore may represent the effects of "basic" strategies related to salt tolerance or susceptibility. The quantification and localization results demonstrate that like "Kaijin", "YNU31-2-4" plants maintained a very low $\mathrm{Na}^{+} / \mathrm{K}^{+}$ratio in both 
shoot and root under salt stress (Figure 5C,F), which is one of the most important mechanisms used by plants to withstand salt stress [76,77]. Under salt stress, the susceptible WT plants had more $\mathrm{Na}^{+}$ densely localized in shoot tissue (Figure 6). An overload of $\mathrm{Na}^{+}$can dramatically depolarize the plasma membrane, leading to $\mathrm{K}^{+}$efflux via depolarization-activated outward-rectifying $\mathrm{K}^{+}$channels [78]. It is notable that $h s t 1$-regulated salt stress resistance involved $\mathrm{K}^{+}$homeostasis. These results suggest that the accumulation of more $\mathrm{K}^{+}$with less $\mathrm{Na}^{+}$in "YNU31-2-4" plants would be mediated by a mechanism of $\mathrm{K}^{+}$influx and $\mathrm{Na}^{+}$efflux. The possible roles of the high-affinity $\mathrm{K}^{+}$transporter OsHKT1;1, upregulated by $h s t 1$, could mediate salt stress resistance in "YNU31-2-4". Further investigation will be needed to elucidate the molecular mechanisms mediating $\mathrm{K}^{+}$and $\mathrm{Na}^{+}$homeostasis in "YNU31-2-4".

In summary, our results demonstrate that the modified biotron breeding system coupled with SNP MAS offers a rapid and effective way to improve single traits in rice. The precise introgression of $h s t 1$, combined with suitable genetic resources and phenotyping results, resulted in the selection of a line, "YNU31-2-4", adapted to salt stress at the vegetative and reproductive stages with improved yield due to improved water relations, photosynthesis, ion homeostasis, regulation of $\mathrm{Na}^{+}$uptake, and xylem loading of $\mathrm{Na}^{+}$to shoot. In order to corroborate the obtained salt stress data, the future perspective of this study is to evaluate the phenotype of the promising line under large-scale field trials. "YNU31-2-4" is a potential candidate for new rice cultivar with markedly improved salinity tolerance, which might sustain grain yield and food security in a changing climate.

\section{Materials and Methods}

\subsection{Planting Materials}

Seeds of "Yukinko-mai" (elite cultivar) and "Kaijin" (salt tolerant) were obtained from the Niigata Agricultural Research Institute's Crop Research Center (Nagaoka city, Niigata, Japan) and the Iwate Biotechnology Research Center (Kitakami city, Iwate, Japan), respectively.

\subsection{Speed-Breeding-Modified Controlled-Biotron Breeding Conditions}

We developed advanced generations using the protocol described by Ohnishi et al. [45] with some modifications. Plants were grown in a growth chamber (CFH-415; Tomy Seiko, Tokyo, Japan) equipped with temperature, light, and humidity controls. Seeds were sterilized in $2.5 \%$ sodium hypochlorite and incubated at $30{ }^{\circ} \mathrm{C}$ in the dark for 2 days. They were then placed on seedling nursery trays and cultured. Ten-day-old seedlings were transplanted ( 1 per pot) into $230-\mathrm{mL}$ plastic pots filled (4/5) with granulated rice nursery culture soil. Plants were grown under a long daylength (14/10 h light/dark) for 30 days to accelerate vegetative growth and then under a short daylength (10/14 $\mathrm{h}$ light/dark) to accelerate reproductive development. The temperature was maintained at $30 / 25^{\circ} \mathrm{Clight} / \mathrm{dark}$. Relative humidity was set to $70 \%$ and light intensity was set to $350 \mu \mathrm{mol} \mathrm{m}^{-2} \mathrm{~s}^{-1}$ (Figure S1). Each plant was restricted to the main culm by removing tillers. The flowers of the female parent were emasculated and pollinated according to Ohnishi et al. [45]. At 10 days after pollination, we rescued embryos from developing seeds and cultured them for 10 days according to the protocol. Healthy rice seedlings were then transplanted and raised to the next breeding step.

\subsection{Developing Salt-Tolerant Line by Backcrossing "Kaijin" to "Yukinko-mai"}

We performed backcrossing to develop an advanced line for salinity tolerance due to the hst 1 gene derived from "Kaijin" using the recurrent parent "Yukinko-mai" (Figure 1A). F1 plants were confirmed as heterozygous at the hst1 (OsRR22) locus by Sanger sequencing, and were backcrossed to "Yukinko-mai" to produce $\mathrm{BC}_{1} \mathrm{~F}_{1}$ plants. We followed the same strategy of selecting plants heterozygous at $h s t 1$ and backcrossing to develop $\mathrm{BC}_{2} \mathrm{~F}_{1}$ and $\mathrm{BC}_{3} \mathrm{~F}_{1}$ generations. Selected $\mathrm{BC}_{3} \mathrm{~F}_{1}$ heterozygous plants were self-pollinated to generate $\mathrm{BC}_{3} \mathrm{~F}_{2}$ lines with the donor allele in the homozygous state. We sequenced the genome of $\mathrm{BC}_{3} \mathrm{~F}_{2}$ line \#31-2-4 to compare with the genomes of the parents. Self-pollinated seeds of line \#31-2-4 were named "YNU31-2-4" $\left(\mathrm{BC}_{3} \mathrm{~F}_{3}\right.$ generation) and used for phenotypic evaluation. 


\subsection{Confirmation of Genotypes by Sanger Sequencing}

We used a PCR primer set to amplify a 545-bp region around the selected SNP (nucleotide 1975 of the OsRR22 locus) [32] from genomic DNA extracted from young leaves of 20-day-old plants using the CTAB method [79]. Well defined PCR product was gel-purified with a High Pure PCR Product Purification Kit (Roche Applied Science, Tokyo, Japan). Sanger sequencing was performed using a BigDye Terminator v. 3.1 Cycle Sequencing Kit (Applied Biosystems, Foster City, CA, USA) on a Prism 3130 Genetic Analyzer (Applied Biosystems). Sequence chromatogram data were visualized in FinchTV software (Geospiza, Inc., Seattle, WA, USA) to determine the genotype at the SNP position.

\subsection{DNA Library Construction and Whole-Genome Sequencing}

Total genomic DNA was extracted from leaves of "Yukinko-mai" and $\mathrm{BC}_{3} \mathrm{~F}_{2}$ line \#31-2-4 according to the protocol of Walbot and Warren [80] with some modifications. The quantity of genomic DNA was tested with a Qubit dsDNA HS Assay Kit (Thermo Fisher Scientific, Inc., Waltham, MA, USA) and the quality was tested by $0.8 \%$ agarose gel electrophoresis. The DNA was sent to Macrogen Japan Corp. (Sakyo-ku, Kyoto, Japan) for Illumina HiSeq X Ten sequencing with NGS libraries prepared by the TruSeq DNA PCR-Free Library Prep Kit (Illumina, Inc., San Diego, CA, USA). The sequence data have been deposited in the DDBJ Sequence Read Archive: DRR151851 $\left(\mathrm{BC}_{3} \mathrm{~F}_{2}\right)$ and DRR151852 ("Yukinko-mai").

\subsection{Read Mapping, Variant Calling, and Variant Annotation}

“Kaijin" whole-genome sequencing reads (DRR021949, DRR021950, DRR021951, DRR021952) were downloaded from public databases. The raw paired-end reads from "Yukinko-mai", $\mathrm{BC}_{3} \mathrm{~F}_{2}$ \#31-2-4, and "Kaijin" sequences were trimmed in Trimmomatic v. 0.33 software [81] with the following parameters: SLIDINGWINDOW, 8:20; TRAILING, 30; MINLEN, 70. The processed reads were mapped to the Nipponbare reference genome (IRGSP-1.0) by using the BWA-MEM v. 0.7.15 algorithm [82]. PCR duplicates in the binary alignment map (BAM) file of "Kaijin" were marked in Picard Tools v. 1.68 software (http://broadinstitute.github.io/picard/). Then indel realignment and base recalculation were done in Genome Analysis Toolkit (GATK) v. 3.6 software [83]. For multi-sample variant calling, we used GATK HaplotypeCaller in gVCF mode followed by GATK GenotypeGVCFs. We filtered out variants with missing data, multi-allelic sites, heterozygous sites in "Kaijin" and "Yukinko-mai", low coverage depth (DP <6), and low quality (QUAL < 20). We further filtered out heterozygous variants in $\mathrm{BC}_{3} \mathrm{~F}_{2} \# 31-2-4$ outside the range of $40 \%-60 \%$ allele frequency by a custom script, and then visualized the genotype map of $\mathrm{BC}_{3} \mathrm{~F}_{2} \# 31-2-4$ in the gtrellis package of $\mathrm{R}$ software [84]. We annotated variants in SnpEff v. 4.0e software [85] and summarized the results in the Python programming language. Sequentially, we extracted "HIGH"- and "MODERATE"-impact variants flagged by SnpEff and performed functional annotation analysis based on two agronomic data sets: data set 1, the Overview of Functionally Characterized Genes in Rice Online (OGRO) database [52]; and data set 2, the potential agronomic functional gene set selected by gene-based GWAS of the Japanese rice population [53]. One of non-synonymous variant in Os09g0356200 was sequenced by Sanger sequencing using forward primer: 5'-cactggaggtcgaaactgct-3' and reverse primer: 5'-tccggtcccagaaatgaagc-3'. The analyses were all based on gene annotation information and genome sequences from the Rice Annotation Project Database (RAP-DB: http://rapdb.dna.affrc.go.jp/).

\subsection{Estimation of Genome Recovery Rate}

We estimated the genome recovery rate of $\mathrm{BC}_{3} \mathrm{~F}_{2} \# 31-2-4$ by calculating the "Yukinko-mai"-type allele frequency out of total variants as:

$$
\text { Genome recovery rate }=\frac{Y Y+Y K / 2}{Y Y+Y K+K K}
$$


where $Y Y=$ number of "Yukinko-mai" homozygous variants, $Y K=$ number of heterozygous variants, and $\mathrm{KK}=$ number of "Kaijin" homozygous variants.

\subsection{Phenotypic Evaluation under Field Condition}

We grew "YNU31-2-4" plants in paddy fields of the Crop Research Center, Niigata University, Japan $\left(37^{\circ} 51^{\prime} 20.75^{\prime \prime} \mathrm{N} 138^{\circ} 57^{\prime} 37.9^{\prime \prime} \mathrm{E}\right)$, during May-September in 2018, to evaluate the major agro-morphological traits. The experiment was laid out in a randomized complete block design with three replications. We used "Kaijin" and "Yukinko-mai" as salt tolerant and high yielding check cultivars, respectively. Thirty-day-old seedlings were transplanted at a spacing of $20 \mathrm{~cm} \times 15 \mathrm{~cm}$. All agronomic practices were performed uniformly for all the genotypes following the local cultural practices. Four uniform looking plants of each genotype from the central row of each replication were selected to determine the phenotype. The major agronomic traits such as (1) flag leaf color, (2) flag leaf length (3) flag leaf width, (4) heading date, (5) plant height, (6) tiller number, (7) panicle number, (8) panicle length, (9) spikelet number, (10) grain number, (11) 1000-grain weight, (12) seed setting rate, (13) grain yield, and (14) above ground biomass were determined. Grain length, width, and thickness were determined with a rice grain grader (RGQI20A; Satake, Hiroshima, Japan).

\subsection{Growth Conditions and Evaluation of Salinity Tolerance at Seedling Stage}

We evaluated "YNU31-2-4" and the parents for seedling-stage salt tolerance in the growth chamber at $26 / 23^{\circ} \mathrm{C}(12 / 12 \mathrm{~h})$ and a relative humidity of $70 \%$. Pre-germinated seeds were placed in $230-\mathrm{mL}$ plastic pots filled with rice nursery culture soil containing $0.5 \mathrm{~g} \mathrm{~N}, 0.9 \mathrm{~g} \mathrm{P}$, and $0.5 \mathrm{~g} \mathrm{~K} / \mathrm{kg}$. The experiment consisted of four treatments: 0 (control), 50, 75, and $125 \mathrm{mM} \mathrm{NaCl}$ (pH 5) The salt stress was imposed ten days after germination. The experiment used four biological replicates, each with 10 seedlings. Phenotype was evaluated 2 weeks after salt was imposed.

\subsection{Determination of Leaf Relative Water Content, Chlorophyll, and Proline}

A separate experiment was conducted to measure biochemical and physiological traits related to salinity tolerance. "YNU31-2-4", "Kaijin", and "Yukinko-mai" seedlings were cultured hydroponically [86]. Ten-day-old rice seedlings were subjected to 0 or $125 \mathrm{mM} \mathrm{NaCl}$ (pH 5.0). Samples were collected 10 days after salt was imposed.

The relative water content (RWC\%) of control and salt-treated leaves was determined according to Sade et al. [87] as:

$$
\% \text { RWC }=(\text { fresh weight }- \text { dry weight }) /(\text { turgid weight }- \text { dry weight }) \times 100
$$

Fully expanded leaves of plants cultured in the absence or presence of salt stress were harvested at the end of the light period, snap-frozen, and ground to a fine powder in liquid nitrogen with a pestle and mortar. Total chlorophyll content was determined according to Lichtenthaler [88]. Free proline content was measured by a colorimetric assay as described by Bates et al. [89].

\subsection{Measurement of $\mathrm{Na}^{+}$and $\mathrm{K}^{+}$Concentrations}

Sodium and potassium ions in shoots and roots were quantified by a wet digestion method [90]. Dried, finely powered plant samples $\left(50 \mathrm{mg}\right.$ ) were digested in $\mathrm{HNO}_{3} / \mathrm{H}_{2} \mathrm{O}_{2}$ solution (2:1) in a microwave oven for 4-5 min until the solution became clear. The digested solution was shaken gently and filtered through $0.2-\mu \mathrm{m}$ filters (Whatman, Maidstone, England), and the solid fraction was discarded. The contents of $\mathrm{Na}^{+}$and $\mathrm{K}^{+}$in the extract were quantified by atomic absorption spectrophotometry (Z-6100, Hitachi, Tokyo, Japan).

For localization of sodium and potassium ions, we prepared samples according to the protocol of Mitsui et al. [91]. Harvested basal portions of shoots were immediately frozen and embedded in OCT compound medium (Sakura Finetek USA, Inc., Torrance, CA, USA), which contained $10.24 \%$ 
$\mathrm{w} / \mathrm{w}$ polyvinyl alcohol, $4.26 \% w / w$ polyethylene glycol, and $85.50 \% w / w$ of a nonreactive ingredient. Then 5- $\mu \mathrm{m}$ sections were scanned with an electron probe microanalyzer (EPMA-1605; Shimadzu, Kyoto, Japan).

\subsection{Evaluation of Salt-Stress Tolerance at Reproductive Stage}

"YNU31-2-4", salt-tolerant "Kaijin", and susceptible "Yukinko-mai" plants were evaluated for salt-stress tolerance at the reproductive stage in a semi-controlled greenhouse. Thirty-day-old seedlings were transplanted (1 per bucket) into 2.5 -L plastic bucket and each treatment had six replicates. Plants were subjected to 0 or $50 \mathrm{mM} \mathrm{NaCl}$ in irrigation water ( $\mathrm{pH}$ ) at 60 days after germination (DAG). After 2 weeks, the salt concentration was increased to $75 \mathrm{mM}$ until booting stage (95 DAG), and then plants were recovered by irrigating with fresh water. The net assimilation rate of penultimate leaves was measured with an LI-6400 gas exchange system (LI-COR Inc., Lincoln, NE, USA) 4 weeks after salt was imposed. Gas exchange was determined at $25{ }^{\circ} \mathrm{C}$ at a photosynthetic photon flux density of $350 \mu \mathrm{mol} \mathrm{m}^{-2} \mathrm{~s}^{-1}$. Yield and its attributes, particularly panicle number, spikelet number, and 1000-spikelet weight were determined at harvest.

\subsection{Statistical Analysis}

Values are presented as mean \pm standard deviation (SD). Means were tested by analysis of variance (ANOVA) followed by Tukey's or Duncan's multiple range test at $p<0.05$ in SPSS software (SPSS Inc., Chicago, IL, USA).

Supplementary Materials: The following are available online at http://www.mdpi.com/1422-0067/20/10/2585/s1. Table S1: Cross-efficiency rate and advanced generation duration in biotron breeding system. Table S2: Annotation of SNPs and indels in $\mathrm{BC}_{3} \mathrm{~F}_{2} \# 31-2-4$. Figure S1: Schematic representation of biotron speed-breeding system. Figure S2: Frameshift deletion in Os09g0356200 affects days-to-heading of YNU31-2-4 plants. Figure S3: Agronomic trait assessment of "Kaijin", WT, and "YNU31-2-4" plants under control field condition. Figure S4: "YNU31-2-4" maintains higher relative water, chlorophyll, and proline contents at the seedling stage under salt stress. Figure S5: "YNU31-2-4" plants have an enlarged root system.

Author Contributions: M.M.R., T.T., M.B., K.K. and T.M. designed the experiments and analyzed the data; M.M.R. performed most of the experiments; T.T. performed the computational analysis of N.G.S. data; K.K., N.H., T.S. and T.O. contributed analytic tools; K.I., T.O., T.K. and H.T. jointly conceived the work; M.M.R., M.B. and T.M. wrote the article with contributions from all authors; and T.M. conceived the project and research plans and supervised the research.

Funding: This research was supported by KAKENHI Grants-in-Aid for Scientific Research (A) (15H02486) from Japan Society for the Promotion of Sciences, Strategic International Collaborative Research Program by the Japan Science and Technology Agency (JST SICORP), and Grant for Promotion of KAAB Projects (Niigata University) from the Ministry of Education, Culture, Sports, Science, and Technology, Japan.

Acknowledgments: Computations were performed on the NIG supercomputer at the ROIS National Institute of Genetics.

Conflicts of Interest: The authors declare no conflict of interest.

\section{References}

1. Wassmann, R.; Jagadish, S.V.K.; Heuer, S.; Ismail, A.; Redona, E.; Serraj, R.; Singh, R.K.; Howell, G.; Pathak, H.; Sumfleth, K. Chapter 2 Climate Change Affecting Rice Production. The Physiological and Agronomic Basis for Possible Adaptation Strategies. Adv. Agron. 2009, 101, 59-122.

2. Welch, J.R.; Vincent, J.R.; Auffhammer, M.; Moya, P.F.; Dobermann, A.; Dawe, D. Rice yields in tropical/subtropical Asia exhibit large but opposing sensitivities to minimum and maximum temperatures. Proc. Natl. Acad. Sci. USA 2010, 107, 14562-14567. [CrossRef]

3. Sreenivasulu, N.; Butardo, V.M.; Misra, G.; Cuevas, R.P.; Anacleto, R.; Kavi Kishor, P.B. Designing climate-resilient rice with ideal grain quality suited for high-temperature stress. J. Exp. Bot. 2015, 66, 1737-1748. [CrossRef] [PubMed] 
4. Calanca, P.P. Effects of Abiotic Stress in Crop Production. In Quantification of Climate Variability, Adaptation and Mitigation for Agricultural Sustainability; Springer International Publishing: Cham, Switzerland, 2017; pp. 165-180.

5. Godfray, H.C.J.; Beddington, J.R.; Crute, I.R.; Haddad, L.; Lawrence, D.; Muir, J.F.; Pretty, J.; Robinson, S.; Thomas, S.M.; Toulmin, C. Food security: The challenge of feeding 9 billion people. Science 2010, 327, 812-818. [CrossRef]

6. United Nations. World Population Prospects: The 2012 Revision. Highlights and Advance Tables. Popul. Dev. Rev. 2013, 36, 775-801. [CrossRef]

7. Munns, R.; Tester, M. Mechanisms of Salinity Tolerance. Annu. Rev. Plant Biol. 2008, 59, 651-681. [CrossRef] [PubMed]

8. Rao, P.S.; Mishra, B.; Gupta, S.R.; Rathore, A. Reproductive stage tolerance to salinity and alkalinity stresses in rice genotypes. Plant Breed. 2008, 127, 256-261. [CrossRef]

9. Negrão, S.; Courtois, B.; Ahmadi, N.; Abreu, I.; Saibo, N.; Oliveira, M.M. Recent updates on salinity stress in rice: From physiological to molecular responses. CRC Crit. Rev. Plant Sci. 2011, 30, 329-377. [CrossRef]

10. Marcos, M.; Sharifi, H.; Grattan, S.R.; Linquist, B.A. Spatio-temporal salinity dynamics and yield response of rice in water-seeded rice fields. Agric. Water Manag. 2018, 195, 37-46. [CrossRef]

11. Todaka, D.; Nakashima, K.; Shinozaki, K.; Yamaguchi-Shinozaki, K. Toward understanding transcriptional regulatory networks in abiotic stress responses and tolerance in rice. Rice 2012, 5, 6. [CrossRef]

12. Horie, T.; Karahara, I.; Katsuhara, M. Salinity tolerance mechanisms in glycophytes: An overview with the central focus on rice plants. Rice 2012, 5, 11. [CrossRef] [PubMed]

13. Roy, S.J.; Negrão, S.; Tester, M. Salt resistant crop plants. Curr. Opin. Biotechnol. 2014, 26, 115-124. [CrossRef] [PubMed]

14. Deinlein, U.; Stephan, A.B.; Horie, T.; Luo, W.; Xu, G.; Schroeder, J.I. Plant salt-tolerance mechanisms. Trends Plant Sci. 2014, 19, 371-378. [CrossRef] [PubMed]

15. Hanin, M.; Ebel, C.; Ngom, M.; Laplaze, L.; Masmoudi, K. New Insights on Plant Salt Tolerance Mechanisms and Their Potential Use for Breeding. Front. Plant Sci. 2016, 7, 1787. [CrossRef] [PubMed]

16. Reddy, I.N.B.L.; Kim, B.-K.; Yoon, I.-S.; Kim, K.-H.; Kwon, T.-R. Salt Tolerance in Rice: Focus on Mechanisms and Approaches. Rice Sci. 2017, 24, 123-144. [CrossRef]

17. Chen, Z.C.; Yamaji, N.; Horie, T.; Che, J.; Li, J.; An, G.; Ma, J.F. A Magnesium Transporter OsMGT1 Plays a Critical Role in Salt Tolerance in Rice. Plant Physiol. 2017, 174, 1837-1849. [CrossRef]

18. Bonilla, D.; Mackill, D.; Deal, K.; Gregorio, G. RFLP and SSLP mapping of salinity tolerance genes in chromosome 1 of rice (Oryza sativa L.) using recombinant inbred lines. J. Agric. Food Chem. 2002, 85, 68-76.

19. Thomson, M.J.; de Ocampo, M.; Egdane, J.; Rahman, M.A.; Sajise, A.G.; Adorada, D.L.; Tumimbang-Raiz, E.; Blumwald, E.; Seraj, Z.I.; Singh, R.K.; et al. Characterizing the Saltol quantitative trait locus for salinity tolerance in rice. Rice 2010, 3, 148-160. [CrossRef]

20. Lin, H.X.; Zhu, M.Z.; Yano, M.; Gao, J.P.; Liang, Z.W.; Su, W.A.; Hu, X.H.; Ren, Z.H.; Chao, D.Y. QTLs for Na ${ }^{+}$ and $\mathrm{K}^{+}$uptake of the shoots and roots controlling rice salt tolerance. Theor. Appl. Genet. 2004, 108, $253-260$. [CrossRef]

21. Ren, Z.-H.; Gao, J.-P.; Li, L.-G.; Cai, X.-L.; Huang, W.; Chao, D.-Y.; Zhu, M.-Z.; Wang, Z.-Y.; Luan, S.; Lin, H.-X. A rice quantitative trait locus for salt tolerance encodes a sodium transporter. Nat. Genet. 2005, 37, 1141-1146. [CrossRef] [PubMed]

22. Vu, H.T.T.; Le, D.D.; Ismail, A.M.; Le, H.H. Marker-assisted backcrossing (MABC) for improved salinity tolerance in rice (Oryza sativa L.) to cope with climate change in Vietnam. Aust. J. Crop Sci. 2012, 6, 1649-1654.

23. Linh, L.H.; Linh, T.H.; Xuan, T.D.; Ham, L.H.; Ismail, A.M.; Khanh, T.D. Molecular Breeding to Improve Salt Tolerance of Rice (Oryza sativa L.) in the Red River Delta of Vietnam. Int. J. Plant Genom. 2012, 2012, 949038. [CrossRef]

24. Gregorio, G.B.; Islam, M.R.; Vergara, G.V.; Thirumeni, S. Recent advances in rice science to design salinity and other abiotic stress tolerant rice varieties. Sabrao J. Breed. Genet. 2013, 45, 31-41.

25. Babu, N.N.; Krishnan, S.G.; Vinod, K.K.; Krishnamurthy, S.L.; Singh, V.K.; Singh, M.P.; Singh, R.; Ellur, R.K.; Rai, V.; Bollinedi, H.; et al. Marker Aided Incorporation of Saltol, a Major QTL Associated with Seedling Stage Salt Tolerance, into Oryza sativa "Pusa Basmati 1121". Front. Plant Sci. 2017, 8, 41. [CrossRef] [PubMed]

26. Quan, R.; Wang, J.; Hui, J.; Bai, H.; Lyu, X.; Zhu, Y.; Zhang, H.; Zhang, Z.; Li, S.; Huang, R. Improvement of Salt Tolerance Using Wild Rice Genes. Front. Plant Sci. 2018, 8, 2269. [CrossRef] 
27. Negrão, S.; Cecília Almadanim, M.; Pires, I.S.; Abreu, I.A.; Maroco, J.; Courtois, B.; Gregorio, G.B.; McNally, K.L.; Margarida Oliveira, M. New allelic variants found in key rice salt-tolerance genes: An association study. Plant Biotechnol. J. 2013, 11, 87-100. [CrossRef]

28. Jain, M.; Moharana, K.C.; Shankar, R.; Kumari, R.; Garg, R. Genomewide discovery of DNA polymorphisms in rice cultivars with contrasting drought and salinity stress response and their functional relevance. Plant Biotechnol. J. 2014, 12, 253-264. [CrossRef] [PubMed]

29. Rahman, M.A.; Thomson, M.J.; Shah-E-Alam, M.; De Ocampo, M.; Egdane, J.; Ismail, A.M. Exploring novel genetic sources of salinity tolerance in rice through molecular and physiological characterization. Ann. Bot. 2016, 117, 1083-1097. [CrossRef] [PubMed]

30. Tiwari, S.; Sl, K.; Kumar, V.; Singh, B.; Rao, A.R.; Sv, A.M.; Rai, V.; Singh, A.K.; Singh, N.K. Mapping QTLs for Salt Tolerance in Rice (Oryza sativa L.) by Bulked Segregant Analysis of Recombinant Inbred Lines Using 50K SNP Chip. PLoS ONE 2016, 11, e0153610. [CrossRef]

31. Mishra, S.; Singh, B.; Panda, K.; Singh, B.P.; Singh, N.; Misra, P.; Rai, V.; Singh, N.K. Association of SNP Haplotypes of HKT Family Genes with Salt Tolerance in Indian Wild Rice Germplasm. Rice 2016, 9, 8. [CrossRef]

32. Takagi, H.; Tamiru, M.; Abe, A.; Yoshida, K.; Uemura, A.; Yaegashi, H.; Obara, T.; Oikawa, K.; Utsushi, H.; Kanzaki, E.; et al. MutMap accelerates breeding of a salt-tolerant rice cultivar. Nat. Biotechnol. 2015, 33, 445-449. [CrossRef] [PubMed]

33. Abe, A.; Takagi, H.; Nakajo, S.; Terauchi, R.; Kuroda, E. Yielding ability and physicochemical characteristics related to eating quality in salt-tolerant rice variety "Kaijin" under normal salt-free cultivated condition. Tohoku J. Crop Sci. 2016, 59, 19-20. [CrossRef]

34. Ishizaki, K.; Matsui, T.; Kaneda, S.; Kobayashi, K.; Kasaneyama, H.; Abe, S.; Azuma, S.; Hoshi, T.; Sasaki, Y.; Hirao, K.; et al. A New Rice Cultivar "Yukinko-mai". J. Niigata Agric. Res. Inst. 2008, 9, 89-98.

35. Shiraya, T.; Mori, T.; Maruyama, T.; Sasaki, M.; Takamatsu, T.; Oikawa, K.; Itoh, K.; Kaneko, K.; Ichikawa, H.; Mitsui, T. Golgi/plastid-type manganese superoxide dismutase involved in heat-stress tolerance during grain filling of rice. Plant Biotechnol. J. 2015, 13, 1251-1263. [CrossRef]

36. Lee, K.-S.; Choi, W.-Y.; Ko, J.-C.; Kim, T.-S.; Gregorio, G.B. Salinity tolerance of japonica and indica rice (Oryza sativa L.) at the seedling stage. Planta 2003, 216, 1043-1046. [CrossRef]

37. Roy, K.; Sasada, K.; Kohno, E. Salinity status of the 2011 Tohoku-oki tsunami affected agricultural lands in northeast Japan. Int. Soil Water Conserv. Res. 2014, 2, 40-50. [CrossRef]

38. Kurotani, K.; Yamanaka, K.; Toda, Y.; Ogawa, D.; Tanaka, M.; Kozawa, H.; Nakamura, H.; Hakata, M.; Ichikawa, H.; Hattori, T.; et al. Stress Tolerance Profiling of a Collection of Extant Salt-Tolerant Rice Varieties and Transgenic Plants Overexpressing Abiotic Stress Tolerance Genes. Plant Cell Physiol. 2015, 56, 1867-1876. [CrossRef] [PubMed]

39. Collard, B.C.Y.; Mackill, D.J. Marker-assisted selection: An approach for precision plant breeding in the twenty-first century. Philos. Trans. R. Soc. B Biol. Sci. 2008, 363, 557-572. [CrossRef] [PubMed]

40. Miah, G.; Rafii, M.Y.; Ismail, M.R.; Puteh, A.B.; Rahim, H.A.; Asfaliza, R.; Latif, M.A. Blast resistance in rice: A review of conventional breeding to molecular approaches. Mol. Biol. Rep. 2013, 40, 2369-2388. [CrossRef] [PubMed]

41. Miah, G.; Rafii, M.Y.; Ismail, M.R.; Puteh, A.B.; Rahim, H.A.; Latif, M.A. Recurrent parent genome recovery analysis in a marker-assisted backcrossing program of rice (Oryza sativa L.). C. R. Biol. 2015, 338, 83-94. [CrossRef]

42. Fukuoka, S.; Ebana, K.; Yamamoto, T.; Yano, M. Integration of Genomics into Rice Breeding. Rice 2010, 3, 131-137. [CrossRef]

43. Luo, Y.; Ma, T.; Zhang, A.; Ong, K.H.; Li, Z.; Yang, J.; Yin, Z. Marker-assisted breeding of the rice restorer line Wanhui 6725 for disease resistance, submergence tolerance and aromatic fragrance. Rice 2016, 9, 66. [CrossRef] [PubMed]

44. Das, G.; Patra, J.K.; Baek, K.-H. Insight into MAS: A Molecular Tool for Development of Stress Resistant and Quality of Rice through Gene Stacking. Front. Plant Sci. 2017, 8, 985. [CrossRef] [PubMed]

45. Ohnishi, T.; Yoshino, M.; Yamakawa, H.; Kinoshita, T. The biotron breeding system: A rapid and reliable procedure for genetic studies and breeding in rice. Plant Cell Physiol. 2011, 52, 1249-1257. [CrossRef] [PubMed] 
46. Tanaka, J.; Hayashi, T.; Iwata, H. A practical, rapid generation-advancement system for rice breeding using simplified biotron breeding system. Breed. Sci. 2016, 66, 542-551. [CrossRef]

47. Collard, B.C.Y.; Beredo, J.C.; Lenaerts, B.; Mendoza, R.; Santelices, R.; Lopena, V.; Verdeprado, H.; Raghavan, C.; Gregorio, G.B.; Vial, L.; et al. Revisiting rice breeding methods-Evaluating the use of rapid generation advance (RGA) for routine rice breeding. Plant Prod. Sci. 2017, 20, 337-352. [CrossRef]

48. Watson, A.; Ghosh, S.; Williams, M.J.; Cuddy, W.S.; Simmonds, J.; Rey, M.D.; Asyraf Md Hatta, M.; Hinchliffe, A.; Steed, A.; Reynolds, D.; et al. Speed breeding is a powerful tool to accelerate crop research and breeding. Nat. Plants 2018, 4, 23-29. [CrossRef]

49. Nagatoshi, Y.; Fujita, Y. Accelerating Soybean Breeding in a $\mathrm{CO}_{2}$-Supplemented Growth Chamber. Plant Cell Physiol. 2019, 60, 77-84. [CrossRef] [PubMed]

50. De Haas, L.S.; Koopmans, R.; Lelivelt, C.L.C.; Ursem, R.; Dirks, R.; Velikkakam James, G. Low-coverage resequencing detects meiotic recombination pattern and features in tomato RILs. DNA Res. 2017, 24, 549-558. [CrossRef] [PubMed]

51. Si, W.; Yuan, Y.; Huang, J.; Zhang, X.; Zhang, Y.; Zhang, Y.; Tian, D.; Wang, C.; Yang, Y.; Yang, S. Widely distributed hot and cold spots in meiotic recombination as shown by the sequencing of rice $\mathrm{F}_{2}$ plants. New Phytol. 2015, 206, 1491-1502. [CrossRef]

52. Yamamoto, E.; Yonemaru, J.-I.; Yamamoto, T.; Yano, M. OGRO: The Overview of functionally characterized Genes in Rice online database. Rice 2012, 5, 26. [CrossRef]

53. Yano, K.; Yamamoto, E.; Aya, K.; Takeuchi, H.; Lo, P.C.; Hu, L.; Yamasaki, M.; Yoshida, S.; Kitano, H.; Hirano, K.; et al. Genome-wide association study using whole-genome sequencing rapidly identifies new genes influencing agronomic traits in rice. Nat. Genet. 2016, 48, 927-934. [CrossRef] [PubMed]

54. Munns, R. Genes and Salt Tolerance. New Phytol. 2005, 167, 645-663. [CrossRef] [PubMed]

55. Inui, T.; Yasutaka, T.; Endo, K.; Katsumi, T. Geo-environmental issues induced by the 2011 off the Pacific Coast of Tohoku Earthquake and tsunami. Soils Found. 2012, 52, 856-871. [CrossRef]

56. Iftekharuddaula, K.M.; Salam, M.A.; Newaz, M.A.; Ahmed, H.U.; Collard, B.C.Y.; Septiningsih, E.M.; Sanchez, D.L.; Pamplona, A.M.; Mackill, D.J. Comparison of phenotypic versus marker-assisted background selection for the SUB1 QTL during backcrossing in rice. Breed. Sci. 2012, 62, 216-222. [CrossRef] [PubMed]

57. Hasan, M.M.; Rafii, M.Y.; Ismail, M.R.; Mahmood, M.; Rahim, H.A.; Alam, M.A.; Ashkani, S.; Malek, M.A.; Latif, M.A. Marker-assisted backcrossing: A useful method for rice improvement. Biotechnol. Biotechnol. Equip. 2015, 29, 237-254. [CrossRef]

58. Tanweer, F.A.; Rafii, M.Y.; Sijam, K.; Rahim, H.A.; Ahmed, F.; Ashkani, S.; Latif, M.A. Introgression of Blast Resistance Genes (Putative Pi-b and Pi-kh) into Elite Rice Cultivar MR219 through Marker-Assisted Selection. Front. Plant Sci. 2015, 6, 1002. [CrossRef]

59. Jagadish, S.V.K.; Septiningsih, E.M.; Kohli, A.; Thomson, M.J.; Ye, C.; Redoña, E.; Kumar, A.; Gregorio, G.B.; Wassmann, R.; Ismail, A.M.; et al. Genetic Advances in Adapting Rice to a Rapidly Changing Climate. J. Agron. Crop Sci. 2012, 198, 360-373. [CrossRef]

60. Ma, Y.-C.; Augé, R.M.; Dong, C.; Cheng, Z.-M.M. Increased salt tolerance with overexpression of cation/proton antiporter 1 genes: A meta-analysis. Plant Biotechnol. J. 2017, 15, 162-173. [CrossRef] [PubMed]

61. Hayat, S.; Hayat, Q.; Alyemeni, M.N.; Wani, A.S.; Pichtel, J.; Ahmad, A. Role of proline under changing environments: A review. Plant Signal. Behav. 2012, 7, 1456-1466. [CrossRef]

62. Saxena, S.C.; Kaur, H.; Verma, P.; Petla, B.P.; Andugula, V.R.; Majee, M. Osmoprotectants: Potential for Crop Improvement Under Adverse Conditions. In Plant Acclimation to Environmental Stress; Springer: New York, NY, USA, 2013; pp. 197-232.

63. Szabados, L.; Savouré, A. Proline: A multifunctional amino acid. Trends Plant Sci. 2010, 15, 89-97. [CrossRef]

64. Gupta, B.; Huang, B. Mechanism of Salinity Tolerance in Plants: Physiological, Biochemical, and Molecular Characterization. Int. J. Genom. 2014, 2014, 701596. [CrossRef]

65. Zeng, L.; Shannon, M.C. Salinity Effects on Seedling Growth and Yield Components of Rice. Crop Sci. 2000, 40, 996. [CrossRef]

66. Walia, H.; Wilson, C.; Zeng, L.; Ismail, A.M.; Condamine, P.; Close, T.J. Genome-wide transcriptional analysis of salinity stressed japonica and indica rice genotypes during panicle initiation stage. Plant Mol. Biol. 2007, 63, 609-623. [CrossRef] [PubMed] 
67. Zhou, Y.-B.; Liu, C.; Tang, D.-Y.; Yan, L.; Wang, D.; Yang, Y.-Z.; Gui, J.-S.; Zhao, X.-Y.; Li, L.-G.; Tang, X.-D.; et al. The Receptor-Like Cytoplasmic Kinase STRK1 Phosphorylates and Activates CatC, Thereby Regulating $\mathrm{H}_{2} \mathrm{O}_{2}$ Homeostasis and Improving Salt Tolerance in Rice. Plant Cell 2018, 30, 1100-1118. [CrossRef]

68. Murchie, E.H.; Yang, J.; Hubbart, S.; Horton, P.; Peng, S. Are there associations between grain-filling rate and photosynthesis in the flag leaves of field-grown rice? J. Exp. Bot. 2002, 53, 2217-2224. [CrossRef]

69. Zhai, H.; Cao, S.; Wan, J.; Zhang, R.; Lu, W.; Li, L.; Kuang, T.; Min, S.; Zhu, D.; Cheng, S. Relationship between leaf photosynthetic function at grain filling stage and yield in super high-yielding hybrid rice (Oryza sativa $\mathrm{L}$ ). Sci. China Ser. C Life Sci. 2002, 45, 637-646. [CrossRef]

70. Kasai, M. Regulation of leaf photosynthetic rate correlating with leaf carbohydrate status and activation state of Rubisco under a variety of photosynthetic source/sink balances. Physiol. Plant. 2008, 134, 216-226. [CrossRef]

71. Sanchez-Bragado, R.; Elazab, A.; Zhou, B.; Serret, M.D.; Bort, J.; Nieto-Taladriz, M.T.; Araus, J.L. Contribution of the ear and the flag leaf to grain filling in durum wheat inferred from the carbon isotope signature: Genotypic and growing conditions effects. J. Integr. Plant Biol. 2014, 56, 444-454. [CrossRef]

72. Zhou, W.; Lv, T.; Yang, Z.; Wang, T.; Fu, Y.; Chen, Y.; Hu, B.; Ren, W. Morphophysiological mechanism of rice yield increase in response to optimized nitrogen management. Sci. Rep. 2017, 7, 17226. [CrossRef] [PubMed]

73. Liu, W.; Li, R.-J.; Han, T.-T.; Cai, W.; Fu, Z.-W.; Lu, Y.-T. Salt stress reduces root meristem size by nitric oxide-mediated modulation of auxin accumulation and signaling in Arabidopsis. Plant Physiol. 2015, 168, 343-356. [CrossRef]

74. Yu, J.; Zhao, W.; Tong, W.; He, Q.; Yoon, M.-Y.; Li, F.-P.; Choi, B.; Heo, E.-B.; Kim, K.-W.; Park, Y.-J.; et al. A Genome-Wide Association Study Reveals Candidate Genes Related to Salt Tolerance in Rice (Oryza sativa) at the Germination Stage. Int. J. Mol. Sci. 2018, 19, 3145. [CrossRef] [PubMed]

75. Ali, A.; Maggio, A.; Bressan, R.; Yun, D.-J.; Ali, A.; Maggio, A.; Bressan, R.A.; Yun, D.-J. Role and Functional Differences of HKT1-Type Transporters in Plants under Salt Stress. Int. J. Mol. Sci. 2019, 20, 1059. [CrossRef]

76. Okada, T.; Nakayama, H.; Shinmyo, A.; Yoshida, K. Expression of OsHAK genes encoding potassium ion transporters in rice. Plant Biotechnol. 2008, 25, 241-245. [CrossRef]

77. Hauser, F.; Horie, T. A conserved primary salt tolerance mechanism mediated by HKT transporters: A mechanism for sodium exclusion and maintenance of high $\mathrm{K}^{+} / \mathrm{Na}^{+}$ratio in leaves during salinity stress. Plant. Cell Environ. 2010, 33, 552-565. [CrossRef]

78. Chen, Z.; Pottosin, I.I.; Cuin, T.A.; Fuglsang, A.T.; Tester, M.; Jha, D.; Zepeda-Jazo, I.; Zhou, M.; Palmgren, M.G.; Newman, I.A.; et al. Root plasma membrane transporters controlling $\mathrm{K}+\mathrm{Na}+$ homeostasis in salt-stressed barley. Plant Physiol. 2007, 145, 1714-1725. [CrossRef]

79. Doyle, J.J.; Doyle, J.L. A rapid DNA isolation procedure for small quantities of fresh leaf tissue. Phytochem. Bull. 1987, 19, 11-15.

80. Walbot, V.; Warren, C. Regulation of Mu element copy number in maize lines with an active or inactive Mutator transposable element system. Mol. Gen. Genet. 1988, 211, 27-34. [CrossRef]

81. Bolger, A.M.; Lohse, M.; Usadel, B. Trimmomatic: A flexible trimmer for Illumina sequence data. Bioinformatics 2014, 30, 2114-2120. [CrossRef] [PubMed]

82. Li, H.; Durbin, R. Fast and accurate short read alignment with Burrows-Wheeler transform. Bioinformatics 2009, 25, 1754-1760. [CrossRef]

83. DePristo, M.A.; Banks, E.; Poplin, R.; Garimella, K.V.; Maguire, J.R.; Hartl, C.; Philippakis, A.A.; del Angel, G.; Rivas, M.A.; Hanna, M.; et al. A framework for variation discovery and genotyping using next-generation DNA sequencing data. Nat. Genet. 2011,43, 491-498. [CrossRef]

84. Gu, Z.; Eils, R.; Schlesner, M. Gtrellis: An R/Bioconductor package for making genome-level Trellis graphics. BMC Bioinform. 2016, 17, 169. [CrossRef] [PubMed]

85. Cingolani, P.; Platts, A.; Wang, L.L.; Coon, M.; Nguyen, T.; Wang, L.; Land, S.J.; Lu, X.; Ruden, D.M. A program for annotating and predicting the effects of single nucleotide polymorphisms, SnpEff. Fly 2012, 6, 80-92. [CrossRef] [PubMed]

86. Yoshida, S.; Forno, D.A.; Cock, J.H.; Gomez, K.A. Laboratory Manual for Physiological Studies of Rice, 3rd ed.; International Rice Research Institute: Manila, Philippines, 1976; pp. 61-66.

87. Sade, N.; Vinocur, B.J.; Diber, A.; Shatil, A.; Ronen, G.; Nissan, H.; Wallach, R.; Karchi, H.; Moshelion, M. Improving plant stress tolerance and yield production: Is the tonoplast aquaporin SITIP2;2 a key to isohydric to anisohydric conversion? New Phytol. 2009, 181, 651-661. [CrossRef] [PubMed] 
88. Lichtenthaler, H.K. Chlorophylls and Carotenoids: Pigments of Photosynthetic Biomembranes. Methods Enzymol. 1987, 148, 350-382. [CrossRef]

89. Bates, L.S.; Waldren, R.P.; Teare, I.D. Rapid determination of free proline for water-stress studies. Plant Soil 1973, 39, 205-207. [CrossRef]

90. Pequerul, A.; Pérez, C.; Madero, P.; Val, J.; Monge, E. A rapid wet digestion method for plant analysis. In Optimization of Plant Nutrition; Springer: Dordrecht, The Netherlands, 1993; pp. 3-6.

91. Mitsui, T.; Loboda, T.; Itoh, A.; Ikarashi, T. Sugar-Controlled $\mathrm{Ca}^{2+}$ Uptake and $\alpha$-Amylase Secretion in Cultured Cells of Rice (Oryza sativa L.). Plant Cell Physiol. 1999, 40, 884-893. [CrossRef]

(C) 2019 by the authors. Licensee MDPI, Basel, Switzerland. This article is an open access article distributed under the terms and conditions of the Creative Commons Attribution (CC BY) license (http://creativecommons.org/licenses/by/4.0/). 